\title{
HISTOLOGICAL BIOMARKERS IN FISH AS A TOOL IN ECOLOGICAL RISK ASSESSMENT AND MONITORING PROGRAMS: A REVIEW
}

\author{
YANCHEVA, V. ${ }^{1}$ - VELCHEVA, I. ${ }^{1}-$ STOYANOVA, S. ${ }^{*}-$ GEORGIEVA, ${ }^{2}$ \\ Plovdiv University, Faculty of Biology, Tzar Assen Str. 24, Plovdiv, 4000, Bulgaria \\ ${ }^{I}$ Department of Ecology and Environmental Conservation \\ ${ }^{2}$ Department of Developmental Biology \\ (phone: +35-932-261-540) \\ *Corresponding author: Stela Stoyanova \\ e-mail: stela.st@abv.bg \\ (Received $5^{\text {th }}$ May 2015; accepted 28 ${ }^{\text {th }}$ Sept 2015)
}

\begin{abstract}
Water contamination, both in freshwater and marine ecosystems, has been a serious environmental problem all over the world in the last few decades. One of the most common anthropogenic pollutants, which enter the water bodies are metals and metalloids with no biological functions ( $\mathrm{As}, \mathrm{Cd}, \mathrm{Hg}, \mathrm{Ni}$ and $\mathrm{Pb}$ ), pesticides and other persistent organic pollutants such as PAHs, PCBs, tributil tins, dioxins, etc. Most of these pollutants tend to accumulate in biota, biomagnify in the food chains and they are also difficult to break down to less harmful substances. In order to better understand the negative effects on living organisms, and particularly fish, biomarkers at different levels (cell, tissue, organism and population) are applied. In addition, the biomarkers at tissue level such as histological alterations in different fish organs give valuable information about the xenobiotic impact. Thus, they are recommended as useful biomarkers in eco-toxicological research, risk assessment and monitoring programs. In the present paper we aimed to review the use of histological alterations in fish organs such as gills, liver and kidney in ecotoxicological studies, based on collected scientific data from the late 1960's until today.
\end{abstract}

Keywords: aquatic contamination, fish, biomarkers, histological alterations

\section{Introduction}

According to López-Barea (1995) human activities induce stress on ecological systems by importing pollutants, modifying habitats, introducing exotic species or removing the native ones and by changing climate. These activities not only affect the survival or the performance of individual organisms, but also the structure and function of natural ecosystems and the diversity of life at several levels of organization, including the number of species, the genetic composition, and the variety of ecosystems and landscapes.

It has been reported that in recent decades the level of foreign compounds in aquatic ecosystems such as heavy metals, pesticides and other persistent organic pollutants has increased alarmingly as a result of domestic, industrial and agricultural effluents (Sekabira et al., 2010; Lushchak, 2011; Mohamaddi et al., 2011; Ondarza et al., 2010, 2011; Pereira et al., 2013; Jörundsdóttir et al., 2014). Contamination of aquatic systems is treating the living organisms and thus, it has attracted the great attention of many researchers around the globe (Dutta and Dalal, 2008). Recently, the Water Framework Directive (WFD) of the European Union specified monitoring programs required to assess the achievement of good chemical and ecological status for all water bodies by 2015 (Sanchez and Porcher, 2009). 


\section{Why use fish in eco-toxicological research?}

According to Water Framework Directive (WFD), fish represent one of the key elements to evaluate the rivers ecological status (Scardi et al., 2008; Hermoso et al., 2010). Fish have also been found to be good indicators of water contamination in aquatic systems because they occupy different trophic levels; they are of different sizes and ages and in comparison with invertebrates, are also more sensitive to many toxicants (Powers, 1989; Barack and Mason, 1990 a,b; Wenderlaar Bonga and Lock, 1992; Wester et al., 1994; Burger et al., 2002). Fish respond to environmental toxic changes with adapting of their metabolite functions (Mishra and Shukla, 2003). They are present virtually in all environments and many species have been found to be susceptible to environmental pollutants (van der Oost et al., 2003). According to de La Torre et al. (2005) monitoring sentinel fish species is widely used to assess the degree of toxicant accumulation and their effects on health status. Fish are also preferred in toxicological research because of their well-developed osmoregulatory, endocrine, nervous, and immune systems compared to invertebrates (Song et al., 2012). In addition, fish may absorb toxicants directly from the surrounding water and sediments (waterborne exposure), or ingest them through contaminated food in the food chain (dietary exposure), enabling the assessment of contaminant transfer through the tropic web (Cid et al., 2001; Fisk et al., 2001; Moiseenko and Kudryavtseva, 2001; Rashed, 2001; Mondon et al., 2001; Mansour and Sidky, 2002; Usero et al., 2004; Mendil and Uluözlü, 2007; Öztürk et al., 2010; Sounderajan et al., 2010). In teleost fish, the gills, liver, kidney and muscles are the tissues most frequently utilized in ecological, toxicological and pathological studies (Sauer and Watabe, 1989; Velcheva, 2006; Heier, et al. 2009) because they are metabolically active tissues and tend to accumulate toxicants at higher levels (Andres et al., 2000; Karadede and Unlu, 2000; Marcovecchio, 2004). Terra et al. (2008) consider that the toxicants enter the fish organism mainly through the gills and consequently, with the blood they reach the parenchymal organs where they retain for a longer time. In addition, according to Kroglund et al. (2008) the toxicant concentrations, particularly in gills reflect the toxicant concentrations in the water where the fish live; whereas, the concentrations in other organs such as liver and kidney represent storage of toxicants.

\section{Biomarkers in eco-toxicological research}

According to van Der Oost et al. (2003); Giari et al. (2008) and Maria et al. (2009) connections must be established between external levels of exposure, internal levels of tissue contamination and early adverse effects and determining the extent and severity of such contamination only by the result of water chemical analysis is insufficient and often overestimates the proportion and duration of exposure to the toxic agent. In the past 25 years, numerous biomarkers have been developed with the objective to apply them for environmental biomonitoring and risk assessment programs (NRC, 1987; McCarthy and Shugart, 1990; Hinton et al., 1992; Peakall, 1992; Hinton, 1994; Bucheli and Fent, 1995; Van Gestel and Van Brummelen, 1996; Shugart and Theodorakis, 1998; Cajaraville et al., 2000; Adams et al., 2001; Triebeskorn et al., 2002; Pandey et al., 2003; Ronisz et al., 2004; Weeb et al., 2005; Martin-Diaz et al., 2006; Schmitt et al., 2007; Martin-Diaz et al., 2008; Álvarez-Muñoz et al., 2009; Weeb and Gangon, 2009; Domingues et al., 2010; Souza et al., 2013; Muñoz et al., 2015). Biomarkers are defined as responses to any exposure evidenced in histological, physiological, biochemical, 
genetic and behavioral modification (Fossi and Marsili, 1997; Fossi, 1998). More recent, van der Oost et al. (2003) defined biomarkers as biological indicators from an exposure to a stressor responding in various ways. Picado et al. (2008) add that biomarkers, which act as early warning signals of the presence of potentially toxic xenobiotics, are useful tools for assessing either exposure to, or the effects of these compounds providing information about the toxicant bioavailability. Pinto et al. (2009) and Viana et al. (2013) suggest that the biomonitoring process should include analyses at different levels of biological organization, from sub-cellular and cellular analysis of tissues and organs, to the of population and community levels. Therefore, studies using biomarkers are essential to complement environmental monitoring in order to control pollution effects on the animals that inhabit the water bodies (Au, 2004; Camargo and Martinez, 2006; Cazenave et al., 2009). In fact, it has been argued that a full understanding of ecotoxicological processes must consider an integrated multi-level approach, in which molecular impact is related with higher-order biological consequences at the individual, population and community levels (Picado et al., 2008). According to NRC (1987); Schlenk (1999) and WHO (1993) biomarkers have been classified into three separate categories that correspond to three major parameters necessary to conduct ecological risk assessments. To perform such an accurate ecological risk assessment, ecological effects, as well as exposure and susceptibility to contaminants must be well-characterized following identification or formulation of a problem. In each of these processes, well-defined biological indicators can be used in certain cases to help make inexpensive predictions regarding the bioavailability (exposure), mechanism of action (effect) and uncertainty of response (susceptibility) elicited by various anthropogenic substances (Schlenk 1999).

\section{Histological alterations as biomarkers}

Histopathology involves the microscopic examination of cells and tissues of an organism and the semi-quantitative determination of histological abnormalities (Yevich and Yevich, 1994; The et al., 1999; Peebua et al., 2006, Costa et al., 2010). Greenfield et al. (2008) and Poleksić et al. (2010) explain that the histological alterations in selected target organs are sensitive biomarkers for xenobiotic effects, they occur earlier and provide a better evaluation of the effects of aquatic pollution than any single biochemical parameter. Therefore, analysis of histological changes in different fish tissues has been widely used for decades as an instrument in aquatic toxicology to monitor acute and chronic situations, and to provide additional information to physicochemical analyses (Wester and Canton, 1986; Wester and Canton, 1991; Johnson et al., 1993; Perry and Laurent, 1993; Schwaiger et al., 1997; Stentiford et al., 2003; Schwaiger et al., 2004; Lang et al., 2006; Nero et al., 2006; Monteiro et al., 2008; van Dyk and Pieterse, 2008; Olarinmoye et al., 2009; van Dyk et al., 2009; Liu et al., 2010; Sousa et al., 2013a, b). In addition, several biomonitoring programs have used the histological changes observed in different fish organs as biomarkers for ecological quality of aquatic ecosystems (Lang et al., 2006; Blazer et al., 2007; Pinto et al., 2009). Braunbeck et al. (1990) and Schwaiger et al. (1997) state that the histopathological alterations can be used as indicators for the effects of various anthropogenic pollutants and they are a reflection of the overall health of the entire population in the studied ecosystem. Furthermore, histology is a sensitive tool for the diagnosis of direct and indirect toxic effects that affect the animal tissues (Braunbeck and Volk, 1993; Bernet et 
al., 1999; Poleksić et al., 1999; Ferreira et al., 2005; Marchand et al., 2009; Fanta et al., 2003; van der Oost et al., 2003; Zimmerli et al., 2007, van Dyk et al., 2009; Grund et al., 2010; Rajeshkumar and Munuswamy, 2011; Paithane et al., 2012). Therefore, it is considered as an excellent method for assessing the environmental quality (Costa et al., 2009). In addition, according to Hinton and Lauren (1990) for field assessments, histopathology is often the easiest method of assessing, both short and long-term toxic effects. On the other hand, Wester and Canton (1991) and Yevich and Yevich (1994) state that the histological methods are relatively labor-intensive and require some experience, but after all they have the considerable advantage that pathological alterations in different tissues (e.g., gills, liver) can be observed individually, thus creating a direct link with physiological functions such as growth, reproduction, respiration and nutrition.

The feasibility of using histopathological parameters in fish as a biomarker for aquatic pollution in marine biomonitoring has been reviewed thoroughly by Au (2004). According to Rabitto et al. (2005) and Oliveira Ribeiro et al. (2006) the exposure of fish to chemical contaminants can induce a number of lesions and injuries to different organs, but the gills and liver represent important target organs suitable for histopathological examination in searching for damages to tissues and cells.

\section{Histological alterations in fish gills}

Fish gills are multifunctional organs involved in ion transport, gas exchange, acidbase regulation and waste excretion (Dang et al., 2001; Gernhöfer et al., 2001; Evans et al., 2005; Oliveira Ribeiro et al., 2005; de La Torre et al., 2005; Vigliano et al., 2006; Nigro et al., 2006; Salamat and Zarie 2012; Singh, 2014). According to Playle (1998) given the fact that the gills account for over $50 \%$ of the surface area of a fish, it is not surprising that one of the major target organs for waterborne toxicants are exactly the gills. Furthermore, according to Carpene and Vašak (1989); Perry and Laurent (1993); Pourang (1995); Tkacheva et al. (2004) and Rosseland et al. (2007) the gills are the main route of toxicants penetration into the fish organism, thus they are the first organs, which come in contact with environmental pollutants and are sensitive subjects for identifying the effects of water toxicants on the fish organism. Thus, the fish metabolism, acting principally through the gills can be seriously damaged since toxicant incorporation occurs mainly through this respiratory organ (Bervoets and Blust, 2003; Sloman, 2007; Terra et al., 2008). Heier et al. (2009) state that as the fish gills can accumulate bioavailable pollutants, their measurement on gills can reflect the speciation of pollutants, and in particular metals in water, which make them a useful tool for assessing metal bioavailability in water. All this helps to understand why in teleost fish the gills are the most frequently utilized in bioaccumulation studies and the pathological damage produced allows defining the toxicity of the environment, making fish highly suitable for evaluating the health of aquatic systems (Mallatt, 1985; Oliveira Riberio et al., 2000; Olsvik et al., 2001; Moiseenko et al., 2005; Ogundiran et al., 2009). The fish gills are also very sensitive to physical and chemical alterations of the aquatic medium such as: temperature, acidification of the water supply due to acid rain, salts and heavy metals, and to any change in the composition of the environment, which is an important indicator of waterborne toxicants (Saber, 2011). Moreover, the gill surface serves as metal-binding ligands and metal bioaccumulation in particular can occur due to positively charged metal species in the water to negatively charged sites on the gills (Playle et al., 1993; Teien et al., 2006 a,b). 
The normal gill morphology of most teleost fish species is described in details by Laurent and Perry (1991); Perry (1997) and Wilson and Laurent (2002). They explain that the gills of most teleost fish are typically composed of four pairs of gill arches, which are supported by a bone skeleton. The gill itself is made up of double rows of filaments, from which arise perpendicularly the lamellae. The filaments come from the gills arches, supported by cartilage (primary lamellae), from which the secondary lamellae exit. The primary lamellae are lined by a squamous epithelium composed by pavement and non differentiated cells. Below that epithelium are lamellar blood sinuses separated by pillar cells. Between the lamellae, the filament is lined by a thick stratified epithelium constituted by several cellular types, such as chloride, mucous and pavement cells. The secondary lamellae are constituted by a simple epithelium where gas exchanges occur. When it comes to biomarkers the gill histological alterations are considered as non-specific biomarkers, which means that many different organic and inorganic contaminants can cause tissue changes. However, they are recognized as a valid and fast method to determine the damage caused in fish by the pollutant exposure (Arellano et al., 1999). Therefore, the gill histological changes have been suggested as useful biomarkers of environmental contamination ( $\mathrm{Au}, 2004$; Fernandes et al., 2007; Flores-Lopes and Thomaz, 2011; Adeogun, 2012; Pereira et al., 2013). There are reports on various histological changes in fish gills from contaminated water, both in field and laboratory conditions after acute or chronic exposure with sublethal toxicant concentrations (Doughtie and Rao, 1983; Lauren and Mcdonald, 1985; Alazemi et al., 1996; Mazon et al., 2002; Rao et al., 2003, 2006; Camargo and Martinez, 2007; Matos et al., 2007; Liu et al., 2010; Velcheva et al., 2010 a,b; Muthukumarave et al., 2013; Sousa et al., 2013 a, b), but it is often difficult to decide whether morphological alterations are adaptive or destructive (Tkacheva et al., 2004). In addition, according to Camargo and Martinez (2007), Ayandiran et al. (2009) and Vigário and Sabóia-Morais (2014) on one hand the toxicants could induce gill histological alterations such as epithelium degeneration and necrosis. On the other hand, fish are able to develop numerous defense mechanisms, which could prevent the toxicant negative effects. These mechanisms are expressed in different morphological changes including edema, proliferation of epithelium and fusion.

The presence of edema along with the detachment of the lamellar epithelium is the first sign of pathology in fish and one of the more frequent lesions observed in gill epithelium of fish exposed to different xenobiotics (Mallatt, 1985; Thophon et al., 2003). Many studies revealed that interstitial edema is one of the more frequent lesions observed in gill epithelium of fish exposed to pollutants such as heavy metals (Karlsson-Norggren et al., 1986; Reid and McDonald, 1988; Hwang and Tsai, 1993; Sola et al., 1995; Bury et al., 1998; Karan et al., 1998; Cengiz and Unlu, 2002; Pane et al., 2004; Cengiz, 2006; Nero et al., 2006; Velmurugan et al. 2009). This histological alteration can also be due to the exposition to other kinds of pollutants, such as endosulfan (Nowak 1992), paraquat (Banaee, 2013) and drugs (Schwaiger et al., 2004). Furthermore, Karan et al. (1998); Arellano et al. (1999); Cengiz and Unlu (2002); De Boeck et al. (2001); Pane et al. (2004); Schwaiger et al. (2004) and Olurin et al. (2006) claim that lifting of lamellar epithelium is another histological change observed, probably induced by the incidence of severe edema. Laurèn and McDonald (1985); Haaparanta et al. (1997); Arellano et al. (1999); Alexopoulos et al. (2003) and Van Heerden et al. (2004) suppose that edema with lifting of lamellar epithelium could serve 
as a mechanism of defense, because separation of the epithelial lamellae increases the distance across, which waterborne pollutants must diffuse to reach the bloodstream.

Hyperplasia in the gill epithelium in different fish species induced by trace metals was reported by Arellano (1999); De Boeck et al. (2001), Van Heerden et al. (2004); Figueiredo-Fernandes et al. (2007); Velmurugan et al. (2007), Mohamed (2009) and Georgieva et al. (2014). These results were also found in fish exposed to other pollutants such as pesticides (Neskovic et al., 1993; Van den Heuvel et al., 2000; Rosety-Rodríguez et al., 2002; Oropeca et al., 2005). De Boeck et al. (2007) think that the proliferative changes can increase the water blood distance and reduce the absorption of xenobiotics, but in turn, decrease the respiratory surface area, which reduces the effectiveness of gas exchange ion uptake. According to FigueiredoFernandes et al. (2007) cell proliferation with thickening of gill filament epithelium is a histological change, which may lead to the lamellar fusion. Cell proliferation with thickening of the gill filament epithelium after heavy metal exposure is described by several authors (Arellano, 1999; De Boeck et al., 2001; Van Heerden et al., 2004), but these results also were found in fish exposed to other pollutants (Randi et al., 1996; Van den Heuvel et al., 2000; Rosety-Rodríguez et al., 2002). On one hand, by adapting to apparently pathological symptoms, the fish may be able to survive the pollution effects (Evans et al., 2005). On the other hand, as stated by Georgieva et al. (2014) the increase in the number of cells would cause an intense mucous secretion and thicken the mucous layer. Thus, the emergence of fusion and additional significant thickening of the filamentous epithelium could have impact on the respiration and osmoregulation processes in the fish body. Lamellar fusion was found in different fish such as Nile tilapia, Oreochromis niloticus exposed to treated sewage water for 96 h (FontaínhasFernandes et al., 2008), in spotted snake head, Channa punctatus exposed to sublethal herbicide concentrations for $96 \mathrm{~h}$ (Butchiram et al., 2009) and in common carp, Cyprinus carpio exposed to 0.029 and $0.041 \mathrm{mg} / \mathrm{L}$ deltamethrin for short-term $96 \mathrm{~h}$ (Cengiz, 2006).

Peuranen et al. (1994) state that observations such as rupture of the branchial epithelium are considered as direct, dose-dependent deleterious effects of the pollutant, while hyperplasia, lamellar fusion and mucous hypersecretion could be signs of branchial defense responses. Epithelial rupture could lead to a negative ion balance and changes in the hematocrit and hemoglobin and could cause severe disturbances in gill respiration. This ruptur explains the ion loss from the plasma, as described by Peuranen et al. (1994). Dutta et al. (1996) observed such changes in catfish Heteropneusteus fossilis exposed to the $4 \mathrm{mg} / \mathrm{L}$ malathion for 24, 48, 72 and $96 \mathrm{~h}$. Epithelial hyperplasia, curling and fusion of the secondary lamellae were noticed in mrigal carp, Cirrhinus mrigala after exposure to sublethal monocrotophos concentrations (Velmurugan et al., 2007) and in mosquitofish, Gambusia affinis after 30 days of exposure to 0.25$0.50 \mu \mathrm{g} / \mathrm{L}$ deltamethrin (Cengiz and Unlu 2006).

Thophon et al. (2003) and Garcia-Santos et al. (2006) refer that lamellar axis vasodilatation can induce changes in the normal structure of pillar cells with consequent loss of their support function and probably is responsible for the emergence of lamellar aneurysms in fish exposed to heavy metals such as cadmium. Similar results are observed by Figueiredo-Fernandes et al. (2006) in Nile tilapia, Oreochromis niloticus, after $0.5,1.0$ and $2.5 \mathrm{mg} / \mathrm{L}$ copper exposure for 21 days. However, Mallat (1985) suggests that these lesions are rarely associated to metals exposition. Severe vasodilatation was reported by Georgieva et al. (2014), but in common carp, Cyprinus 
carpio exposed to sublethal pesticides concentrations. Aneurisms are the most severe alteration in the fish venous system and they are a result from extended vasodilatation with the collapse of pillar cells and the breakdown of vascular integrity (Martinez et al., 2004; Cengiz, 2006). Garcia-Santos et al. (2006) and Stentiford et al. (2003) observed an increased frequency of this serious alteration in fish from contaminated areas and affirmed that it can be associated with the presence of toxicants such as metals in the water. Monteiro et al. (2005) proved that aneurisms might be used as a sensitive and reliable biomarker of acute copper exposure.

Degenerative changes and necrosis in the fish gill epithelium were reported in the work of Santhakumar et al. (2001), Butchiram et al. (2009) and Hasan et al. (2014) after heavy metal and pesticide exposure.

Overall, as stated by $\mathrm{Au}$ (2004) the response of the fish gill to inorganic and organic pollutant exposure seems not to be affected by the biology of the fish (sex and age) or seasonal factors. However, we can add that some fish species are more sensitive than others to pollutants (trout, salmon) and other are more resilient to contaminated water (carp, perch). It is also important to note that even though all of the above histological alterations can be found in fish exposed to toxicants, some of them induce more severe tissue changes than others. In general, the gill histopathology appears to be a promising biomarker for general environmental contamination, although tissue preparation for gill histopathological study is time consuming (Oliveira Ribeiro et al., 2006).

\section{Histological alterations in fish liver}

Once the toxicants cross the biological barriers and enter the bloodstream, they will reach and accumulate in the fish internal organs. Numerous studies have quantified contaminants in different fish organs to evaluate environmental quality, seeking causal relationships with fish health, and, based on these, the liver is likely to be the best choice, followed by the kidney and gills (Begun et al., 2004; Pokorska et al., 2012; Majnoni et al., 2013). According to Hinton and Laurén (1990), Van der Oost et al. (2003) and Salamat and Zarie (2012) the liver is a detoxification organ and it is essential for both, the metabolism and the excretion of toxic substances in the fish body. According to Mohamed (2009) the liver is also a target organ due to its large blood supply, which causes noticeable toxicant exposure. Moreover, the liver is reported to be the primary organ for bioaccumulation and thus, has been extensively studied in regards to the toxic effects of different xenobiotics (Hinton and Laurén, 1990; Yilmaz et al., 2007; van Dyk et al., 2007; Simonato et al., 2008; Madureira et al., 2012; Nunes et al., 2015).

According to Vicenti et al. (2005) and Figueiredo-Fernandes et al. (2007) healthy teleost fish generally exhibits a normal architecture with a typical parenchymatous appearance with no pathological abnormalities. The parenchyma itself is primarily composed of epithelial cells (hepatocytes) typically with a large central nucleus and homogenous cytoplasm. The hepatocytes are located among blood capillaries called sinusoids forming a cord-like structure known as hepatic cell cords. The lumen of sinusoids contain mainly erythrocytes. The venous blood enteres the liver caudally from the intestine via the hepatic portal veins and branches into the sinusoids. They are lined with reticuloendothelial cells, which are in turn surrounded by hepatocytes. 


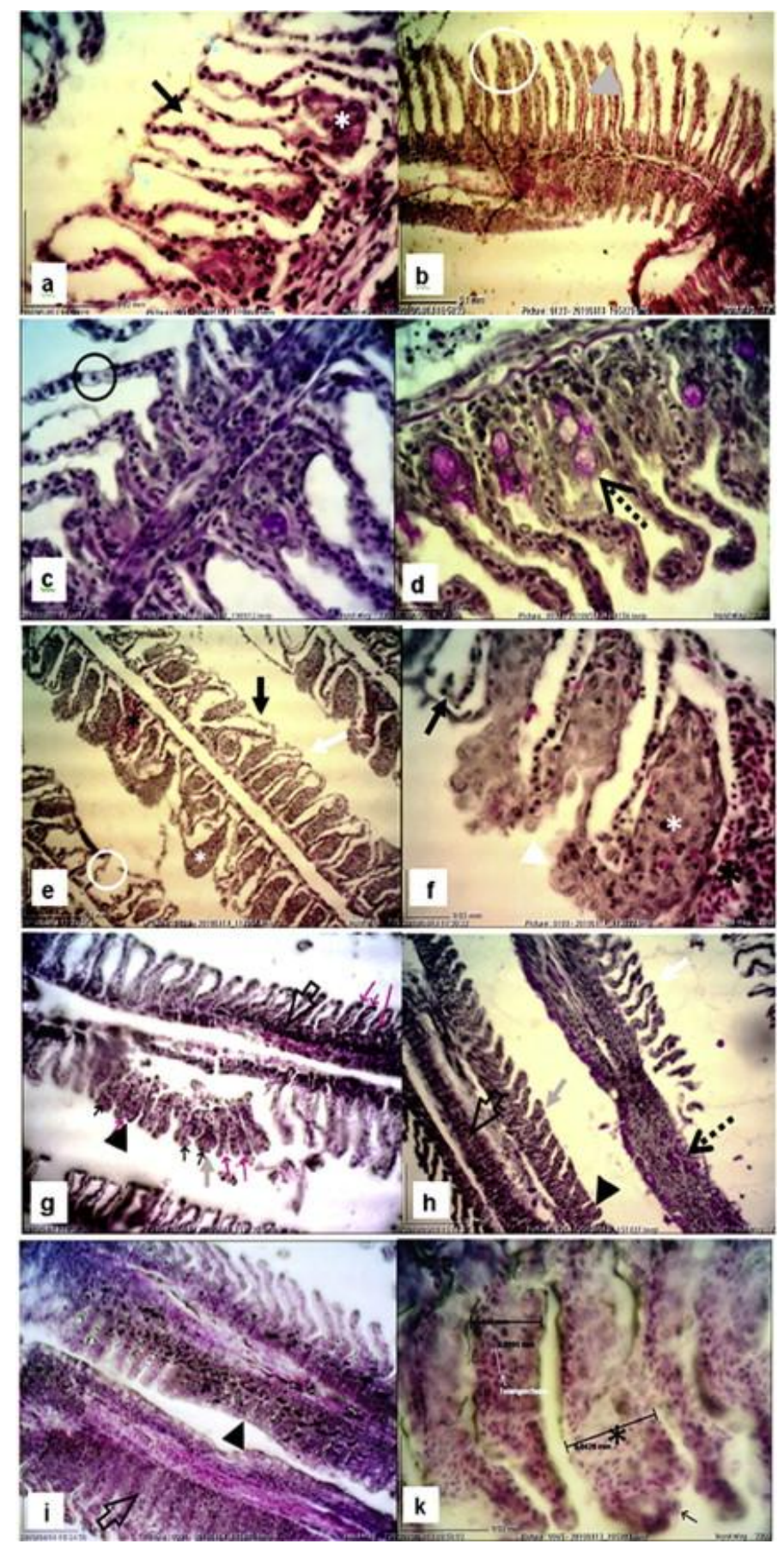

Figure 1. Photomicrographs of histopathological alternations of gills within the A. latus groups exposed to $\mathrm{HgCl}_{2}$; extensive epithelial lifting and edema of the lamellae with enlarged subepithelial spaces (black arrows), hyperplasia of the epithelial cells (white *) with partial fusion of the lamellae (black arrowhead), club shaping of gill lamellae (gray arrow), lamellae with the marginal channel dilated (black marked circularly), blood congestion (gray arrowhead), lamellar aneurysm (black*) within the lamellae, lamellar disorganization (white arrow), hypertrophy of the lamellar epithelium (white arrowhead), leukocytes infiltration (hollow arrow), increase of mucosal cells (dashed arrow), epithelium rupture (white marked circularly); $(a-c)$ Sea breams treated with $10 \mu \mathrm{g} / \mathrm{L} \mathrm{HgCl}_{2}$ (group 1); (d-f) Sea breams treated with $20 \mu \mathrm{g} / \mathrm{L}$ $\mathrm{HgCl}_{2}$ (group 2),; (g and h) Sea breams treated with $35 \mu \mathrm{g} / \mathrm{L} \mathrm{HgCl}$ (group 3); and (j and $\mathrm{k}$ ) Sea breams treated with $50 \mu \mathrm{g} / \mathrm{L} \mathrm{HgCl} 2$ (group 4). (a-c, fand $\mathrm{k}$ ) (H\&E; $\times 2900)$; (e, g and i) (H\&E; $\times 725)$; $(d$ and $h)(P A S ; \times 725)$ (Hassaninezhad et al., 2014). 
Evaluation of the fish liver histopathology is a monitoring tool that can provide an assessment of the effects of environmental stressors on fish populations (Hinton and Lauren, 1990; Fernandes et al., 2008). Also, it was proposed to be one of the most reliable indicators for health impairment of aquatic animals by anthropogenic activities (Hinton and Laurén, 1990; Hinton et al., 2001; Stentiford et al., 2003), since the liver plays an important role in many vital functions (Moon et al., 1985; Triebskorn et al., 2002; Figueiredo-Fernandes et al., 2006; Lang et al., 2006). Several studies carried out in coastal waters have shown correlation between environmental contaminants, bad water quality and occurrence of toxicopathic liver lesions in fish (Vethaak et al., 1992; Vethaak et al., 1996; Stentiford et al., 2003; Feist et al., 2004; Carvalho Neta et al., 2014). Thus, according to Lang (2002) and Feist et al. (2004) in recent years, the fish diseases and liver histopathological alterations have been used as indicators of pollution effects and have been implemented in monitoring programs. Stentiford et al. (2003) state that numerous categories of liver pathology are present as reliable biomarkers of toxic damage. The presence of inflammatory lesions, hepatocellular fibrillar inclusions, and preneoplastic and neoplastic lesions is higher in fish captured in polluted environments than in fish from reference sites. However, accoreding to Pinto et al. (2009) the sort of histological alterations observed depends on individual exposition time to pollutants, as well as on pollutant type and concentration. Triebskorn et al. (1997) and Schramm et al. (1998) described methods to study the liver ultrastructure using quantitative and semi-quantitative electron microscopy.

Similarly to the gill histological alterations, the hepatic alterations are also considered as non-specific biomarkers as many different toxicants can produce liver changes. Exposure to heavy metals and different organic pollutants for example may cause histological changes in the liver and a histological investigation of exposed specimens may therefore produce meaningful results (van Dyk et al., 2007; Triebeskorn et al., 2008; Marchand et al., 2009; Hued et al., 2012; Georgieva et al., 2014). Figuieredo-Fernandes et al. (2007) suggest that high metal deposition in the fish liver leads to the abnormalities in the hepatic structure and hepatocytes, which can lead to subsequent cell death.

Wild fish hepatic lesion appearance and increment can be pointed as a sign of bad water quality and have been the subject of many studies (Vethaak et al., 1992; Simpson et al., 2000; Stentiford et al., 2003). According to Pinto et al. (2009) the sort of histological alterations observed depends on individual exposition time to pollutants, as well as on pollutant type and concentration.

According to Strüssmann and Takashima (1990) morphometric parameters such as number of hepatocytes, hepatocyte area core region of hepatocytes, glycogen content and lipids into the cytoplasm are commonly used as an indicator for hepatocyte metabolic activity.

Monteiro et al. (2005) and Rajeshkumar and Munuswamy (2011) consider that the degenerative alterations such as granular, vacuolar, hydropic and fatty degeneration are from biochemical disturbances, including the inhibition or activation of enzyme activity, changes in protein synthesis, impaired ion regulation, and the depletion of energy resources.

In scientific literature it is stated that cellular swelling occurs either directly by denaturation of volume-regulating ATPases or indirectly by disruption of the cellular energy transfer processes required for ionic regulation (Hinton and Laurén, 1990). Alterations in liver hepatocytes associated with stress were studied long ago by Metelev 
et al. (1971) who reported formation of vacuoles in the hepatocytes. Today vacuolations of hepatocytes is a common response associated with exposure to many different toxicants as described by Mishra and Mohanty (2008) and Vinodhini and Narayanan (2009). Such histological changes could represent lesions at biochemical level, including inhibition of protein synthesis and energy depletion. In addition, vacuolation of hepatocytes in mrigal carp, Cirrhinus mrigala was found after exposure to the pesticide lambda-cyhalothrin for 10 days (Velmurugan et al., 2007), as well as in catfish, Corydoras paleatus after exposure to the pesticide methyl parathion (Fanta et al., 2003). Moore et al. (1997) studied hydropic vacuolation in winter flounder, Pleuronectes americanus from chemically contaminated habitats. According to these authors, grossly visible foci of vacuolation correspond to the most advanced stage of this lesion and is associated with neoplasias. Similarly, Stehr et al. (1998) observed and described hydropic vacuolation in the liver of three species of bottom fishes from US West Coast (Platichthys stellatus, Genyonemus lineatus and Lepidopsetta bilineata). These authors observed single large, hydropic-appearing vacuoles that almost completely filled each affected cell, with little cytoplasm remaining. The edges of the vacuoles were smooth, as if they were membrane-bound, and the vacuoles appeared to be empty. The nucleus was eccentrically located within the vacuole. They also observed that this lesion can appear, in mild cases, like single cells and small groups of two to three cells affected, diffusely distributed throughout the liver. On the other hand, with smaller frequency they identified a focal form of this lesion, where nearly all of the cells within a specific area or "focus" were affected. Lang et al. (2006) found hydropic vacuolation in Baltic flounder, Platichthys flesus, which was used as indicator for biological effects of contaminants.

Yancheva et al. (2015) found hepatocytes, which were morphologically altered and resembled typical adipose cells with flattened nucleus located on the periphery in fish from a metal-contaminated lake. Marty et al. (2003) studied demersal rockfish species from Prince William Sound, AK, USA, after the ExxonValdez oil spill in 1989 and detected some hepatic microlesions, such as pigmented macrophage aggregates and hepatic megalocytosis, fibrosis and lipid accumulation. In that study, it was confirmed that in fish with abundant hepatic lipid (lipid accumulation), the hepatocyte cytoplasm contained variable amounts of clear, round, well-demarcated vacuoles and some cells contained multiple cytoplasmic vacuoles. According to Pinto et al. (2009) this histological change could represent several biochemical lesions, such as inhibition of protein synthesis, energy depletion, disaggregation of microtubules and shifts in substance utilization. This lesion can appear under two forms: foci of variable size or disperse by whole hepatic parenchyma. Cristiane de Melo et al. (2008) found in the cytoplasm of hepatocytes of catfish, Rhamdia quelen exposed to $0.01 \mathrm{ml} / \mathrm{L}$ Folidol 600 a higher presence of lipid droplets in the first $48 \mathrm{~h}$ than in the control fish. According to Arellano et al. (1999), this lipid deposition can indicate a possible alteration in the fat metabolism of the hepatocytes. In the fish thinlip mullet, Liza ramada, BiagiantiRisbourg and Bastide (1995) described different sizes of lipid droplets according to the time of sub-lethal exposure to the herbicide atrazine.

Several studies demonstrated that alterations in number, size and shape of the hepatocyte nucleus can be due to contaminants. Alterations in the size of nucleus were previously regarded by Paris-Palacios et al. (2000) in zebrafish, Brachydanio rerio exposed to sub-lethal concentrations of copper sulphate. Braunbeck et al. (1990 a,b) state that alterations in size and shape of nucleus have often been regarding as signs of 
increased metabolic activity, but may be also of pathological origin. Ahmad et al. (2002) claim that disturbances in the osmotic regulation of cellular membranes result in increasing the volume of the nuclei and nucleoli, and this lead to necrosis of liver cells. Ayoola (2008) found that the fish liver exposed to glyphosate had infiltration of leukocytes, increased hepatocyte size with pyknotic nuclei and presence of vacuoles. Alterations such as irregular shaped hepatocytes and cytoplasmatic vacuolation were also described in populations of mullets (Coz-Rakovac et al., 2008) and sea bass (CozRakovac et al., 2005) aggregated around fish farms.

Varanka et al. (2001) suggest that metal accumulation in the liver of common carp, Cyprinus carpio causes hepatocyte lysis, cirrhosis and ultimately death. Braunbeck (1994) reported proliferation of lysosomes in the hepatocytes of rainbow trout (Oncorhynchus mykiss) following in vivo and in vitro sub-lethal exposure to xenobiotics (e.g. 4-chloroaniline). Nero et al. (2006 a,b) conducted a study with yellow perch, Perca flavescens and caged goldfish, Carassius auratus held in waters containing high levels of oil sands process-affected water and observed that following a 3-week exposure, liver histopathological change were observed in the individuals. In relation to significant changes in liver histopathology, it was dominated by degenerative alterations for both species and, to a lesser extent, inflammatory (yellow perch) and cytoplasmic (goldfish) alterations. Necrotic foci and nuclear pleomorphism dominated the degenerative lesions in both fish species.

Figueiredo-Fernandes et al. (2006) and Ada et al. (2012) found increased macrophages and eosinophil cells in Nile tilapia, Oreochromis niloticus liver under sublethal paraquat exposure.

Do Carmo Langiano and Martinez (2008) found degenerative changes in the hepatic cytoplasm and nuclei, as well as hyperemia in liver of rainbow trout (Oncorhynchus mykiss) and Atlantic salmon (Salmo salar) after 7.5 and $10 \mathrm{mg} / \mathrm{L}$ Roundup exposure for 6, 26 and $96 \mathrm{~h}$.

Ramírez-Duarte et al. (2008) determined $\mathrm{LC}_{50}$ for glyphosate for Amazonic pacu, Piaractus brachypomus. At these concentrations the authors found degenerative changes in the fish liver such as hyaline droplets and lipid vacuolation in the cytoplasm. Walter et al. (2000) and Matos et al. (2007) also determined lipid accumulation in liver of Nile tilapia, Oreochromis niloticus after chronic exposure with dioxin and carbaril, respectively. Similar results were also reported by Gultekin et al. (2000) and Teh et al. (2005). Gaafar et al. (2010) found single hyaline droplets, combined with vacuole degeneration and necrosis in fish liver after fungicide exposure for $96 \mathrm{~h}$.

El-Serafy et al. (2009) determined reduction in the carbohydrates content in the liver of Blue tilapia, Oreochromis aureus after sub-lethal $\left(20 \%, 40 \%\right.$ and $80 \%$ of $\left.\mathrm{LC}_{50}\right)$ phenol exposure for 7 days. Similar results were reported by Pathan et al.(2009 a,b), De Boeck et al. (2010) and Wiseman and Vijayan (2011) after other organic contaminants. On the other hand, Ramesh and Saravanan (2008) found increased glycogen level in the liver of common carp, Cyprinus carpio after chlorpyrifros treatment.

According to Simenova (1999); Rabitto et al. (2005); Mela et al. (2007) and Carrola et al. (2009) the presence of necrotic areas is one of the most serious alterations in liver structure that can occur under the influence of metals. Roberts (1989) explains that necrosis can be characterized by nuclear and cytoplasmic alterations, followed by loss of the cellular contours. When the necrosis of a cell occurs there is the release of chemical signals that induce cell proliferation for the substitution of the dead cells, and so the tissue does not loose its structural and functional condition. Manahan (1991) state 
that the occurrence of necrosis is also a consequence of enzymatic inhibition, damages in the cellular membrane integrity, and disturbances in the synthesis of proteins and carbohydrate metabolism. In fish liver, the presence of necrosis area is also related with xenobiotic concentration during the detoxifying process. Ayoola (2008) and Olufayo and Alade (2012) consider that necrosis of some areas in the liver tissue were probably resulted from the excessive work required by the fish to get rid of the toxicant during the process of detoxification by the liver. Cengiz and Unlu (2006) determined hepatic necrosis in mosquitofish, Gambusia affinis due to sublethal effects of deltamethrin. Necrosis focuses were also observed in the liver of the fossil cat, Heteropneustes fossilis (Dutta et al., 1993), zebrafish, Danio rerio (Rodrigues and Fanta, 1998) and rainbow trout, Onchorynchus mykiss (Uguz et al., 2003) exposed to different pollutants.

Devi and Mishra (2013) and Chamarthi et al. (2014) found leucocytes infiltration in Channa punctatus and Cyprinus carpio liver under chlorpirifos and kinalfos exposure. In addition, Al-Mamoori et al. (2014) determined such histophatological changes, as well as, vasodilatation in small blood vessels and necrosis in Cyprinus carpio liver after acute and chronic exposure with $0.05 \mathrm{mg} / \mathrm{L}, 0.1 \mathrm{mg} / \mathrm{L}, 0.25 \mathrm{mg} / \mathrm{L}$ chlorfos.

Yancheva et al. (2015) found venous hyperaemia in perch from a metalcontaminated lake, which was assumed to be linked to disturbances in the hepatic blood circulation. It was presented in the major and small blood vessels, as well as hepatic sinusoids, most likely due to common vein congestion. Van Dyk et al. (2007) consider that liver hyperemia can lead to hepatic necrosis and atrophy. McHugh et al. (2011) found that the liver alterations in fish exposed to pesticides were mostly associated with circulatory disturbances, related to pathological conditions of blood and tissue fluid flow and regressive changes. They included dilation of blood sinusoids, as well as cytoplasmic granular degeneration and vacuolation of the hepatocytes.

Overall, similarly to the histological alterations in the gills, we can conclude that there are many different (mild or severe) liver changes, which can be induced by both, organic and inorganic toxicants. It also seems that most of them are destructive rather than adaptive. This can be linked with the inability of the detoxification organ to get rid of the contaminants, thus also indicating biochemical disturbances in the fish body.

\section{Histological alterations in fish kidney}

The vertebrate kidney is the main organ involved in the maintenance of body fluid homeostasis. The morphology and function of the kidney have been modified through evolution to fulfill different physiological requirement and the widest range of kidney types is found in fishes (Hentschel and Elger, 1989).

In teleosts, the kidney, together with the gills and intestine, are responsible for excretion and the maintenance of the homeostasis of the body fluids (Hinton et al., 1992; Evans, 1993; Ojeda et al., 2003) and, besides producing urine, acts as an excretory route for the metabolites of a variety of xenobiotics to, which the fish may be exposed (WHO, 1991; Hinton et al., 1992; Eisler, 1998). The kidney also excretes other nitrogen-containing waste products from the metabolism such as ammonia and creatinine. In addition, in fish as in higher vertebrates, the kidney performs an important function related to electrolyte and water balance and the maintenance of a stable internal environment (Cengiz, 2006). 

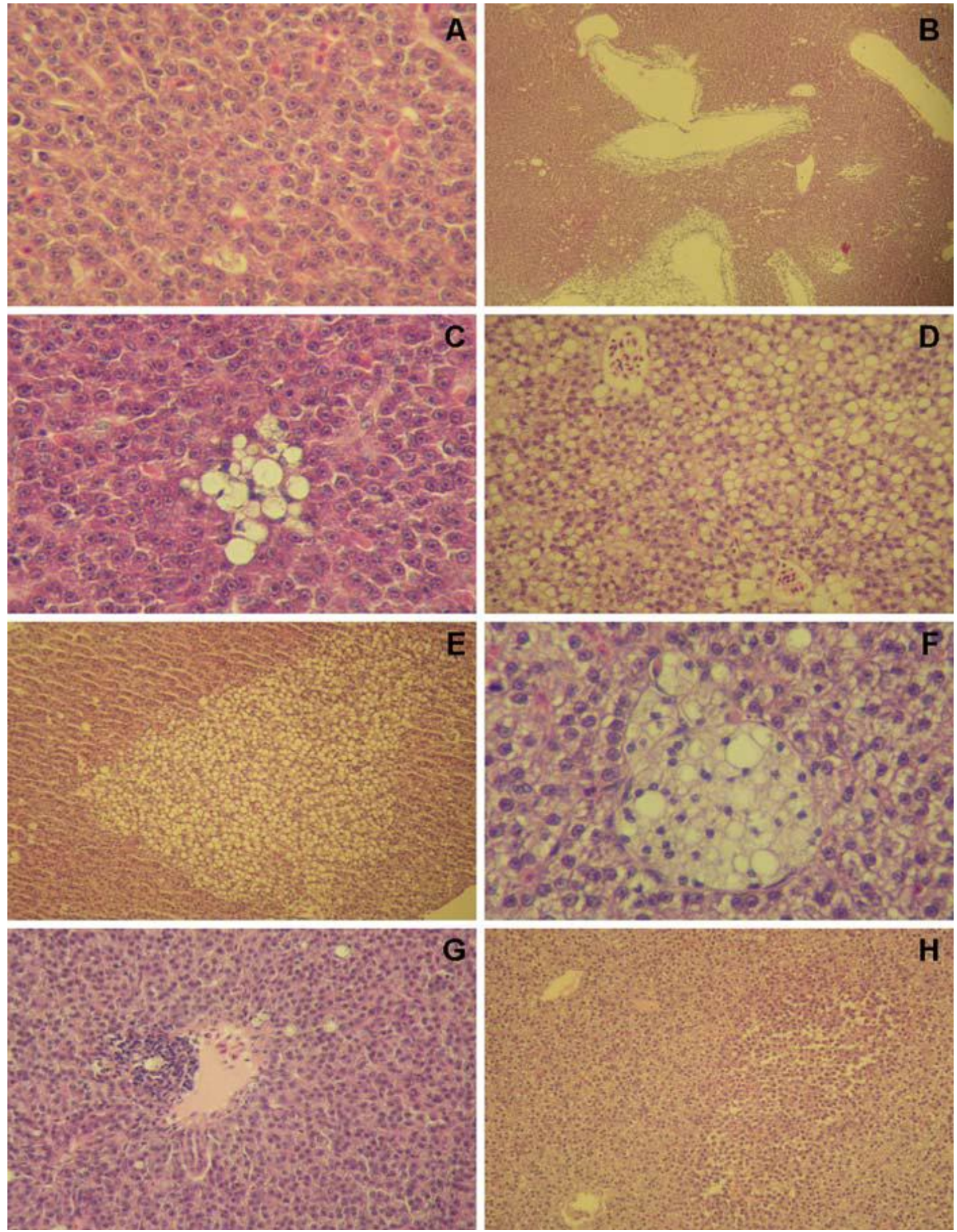

Figure 2. Liver light microscopy of histological sections of gudgeon (G. gobio) caught in

Febros River. A Hepatic parenchyma (reference), where it is shown the homogeneity of hepatocytes distribution (H\&E-×800); B relatively large perivascular necrosis ( $H \& E-\times 80) ; C$

hydropic vacuolation foci, showing a small aggregate of large vacuoles, with hydropic appearance and where the hepatocyte nuclei have an outlying position $(H \& E-\times 800)$; D lipidic vacuolation diffusely distributed in the hepatic parenchyma $(H \& E-\times 400) ;$ E lipidic vacuolation foci, aggregates of several small, clear, and rounded vacuoles $(H \& E-\times 200) ; F$ unspecific granuloma, where it is possible to observe the clear and homogeneous acelullar content, with a well defined margin ( $H \& E-\times 800)$; $G$ small lymphocytic foci close to a blood vessel $(H \& E-$ $\times 400$ ); H disaggregated cells foci, in this area, the hepatocytes are slightly moved away from each other and their walls seems to be disintegrated (H\&E-×400) (Pinto et al., 2009). 
Mobjerg et al. (2004) describe that the kidney of all vertebrates is made up of nephrons, which are the functional, structural and adaptation process. Teleostean kidney consists of anterior kidney (also known as head kidney) and posterior kidney (also known as body or trunk kidney). Embriologically, anterior kidney derives from pronephros, and posterior kidney from mesonephros (Takashima and Hibiya, 1995).

The anterior kidney is integrated into the endocrine system of the fish and is very important for the stress response, mediated by the hypothalamus-pituitary-interrenal cell (HPI) axis and by the hypothalamus-sympathetic nervous system-chromaffin tissue (HSC) axis (Donaldson, 1981; Wendelaar Bonga, 1997).

In addition, the head of kidney contains endocrine elements - the chromaffin cells and interrenal tissue, which are located around the blood vessels. The posterior kidney contains the nephrons with variable quantities of hemopoietic and lymphoid tissue in the interstitium. It is mainly composed of renal corpuscles that are made up of the Bowman's capsules, glomeruli, renal tubules and collecting ducts. In vertebrates, three types of kidney are found: the pronephros, mesonephros and metanephros (Federova, 1998; Mobjerg et al. 2004).

The morphology of the kidney of each species of teleost often reflects the osmotic demands placed on the organism by the environment (Hickman and Trump, 1969). Thus, the freshwater fishes are faced with the need to produce copious amounts of dilute urine and, therefore, their kidneys have well developed renal corpuscles and both, proximal and distal segments in the tubules (Hentschel and Elger, 1987). In contrast, marine fishes have to conserve water and produce small amounts of concentrated urine and consequently their kidneys are either aglomerular (no renal corpuscles) or with poorly developed renal corpuscles (Yousin et al., 1989).

The kidney in fish receives the largest proportion of postbranchial blood, and therefore renal lesions might be expected to be good indicators of environmental pollution (Hinton and Laurén, 1990; Ortiz et al., 2003; Kurtovic et al., 2008). Therefore, Hinton et al. (1992); Oliveira Ribeiro et al. (1996); Schwaiger (2001) and Pacheco and Santos (2002) consider that the effects of pollutants on fish kidneys have been studied in some species and the severity of damage seen depends on the sensitivity of the species to the substances released into the environment (similarly to the gills and liver).

Most common alterations found in the kidney of fishes exposed to water contamination are tubule degeneration (cloudy swelling and hyaline droplets) and changes in the corpuscle, such as dilation of capillaries in the glomerulus and reduction of Bowman's space (Takashima and Hibiya, 1995). Following exposure of fish to toxic agents such pesticides, histological alterations in the fish kidney were found at the level of the tubular epithelium and glomerulus (Teh et al., 1997; Thophon et al., 2003). Yildirim et al. (2006), mentioned that hyaline droplets formation results from tubular reabsorption of plasma protein lost to the urine by glomerular damage. Hyaline degeneration in kidney was observed by Boran et al. (2010) in rainbow trout Oncorhynchus mykiss, after $0.10 \mathrm{mg} / \mathrm{L}$ to $2.00 \mathrm{mg} / \mathrm{L}$ maneb and $0.20 \mathrm{mg} / \mathrm{L}$ to $3.90 \mathrm{mg} / \mathrm{L}$ carbaryl exposure for 24, 48, 72 and $96 \mathrm{~h}$.

Shrinkage of the glomerulus and increased space within the Bowman's capsule were also observed by Ortiz et al. (2003) after lindane exposure. Distal convoluted tubules decreased in size and formations of vacuoles were reported by Tilak et al. (2005) after butachlor exposure for 10 days.

Exposure to metals frequently causes alterations in the tubules and glomerulus, such as was described by Thophon et al. (2003) in perch, Lates calcarifer exposed to sub- 
lethal cadmium. Handy and Penrice (1993) found swollen Bowman's capsule cells and melanomacrophages in the kidney of trout, Salmo trutta and tilapia, Oreochromis mossambicus exposed to mercuric chloride. Similar alterations were found in fishes exposed to organic contaminants (Veiga et al., 2002) and mixed environmental contaminants (Schwaiger et al., 1997; Pacheco and Santos, 2002).

Dilation of the lumina of the kidney tubules, necrosis of tubules, shrinkage of glomerular tuft, vacuolation blood cells in the glomerular tuft have been reported in fossil cat, Heteropneustes fossilis exposed to chlorpyrifos for $96 \mathrm{~h}$ (Srivastava et al., 1990). Elsan treatment in Channa punctatus resulted in a significant decrease in the dimension of Bowman's capsule and glomerulus, and the tubules lost their regular shape due to precipitation of cytoplasm and karyolysis for 90 days (Banerjee and Bhattacharya, 1994). Dass and Mukherjee (2000) reported dilation of tubules, necrotic changes characterized by karyorrhexis and karyolysis at the nuclei of affected cells of carp, Labeo rohita, exposed to 1/10 and 1/5 sub-lethal doses hexachlorocyclohexane after 45-day test period. Ortiz et al. (2003) showed tubular necrosis, desquamation and vacuolisation of tubular epithelial cells in Mugil sp., Cyprinus carpio and Barbus sp. kidney exposed to lindane ( $\gamma$-Hexachloro-cyclohexane $-\gamma$-HCH-).

Lauren et al. (1989) found tubular degeneration and eosinophilic, proteinacious, intratubular casts and hyaline droplets, and an increase in the amount of hemosiderin or melanin-like intertubular deposits in rainbow trout, Salmo gairgneri fed with the antibiotic fumagilin. Hyaline droplet formation results from tubular reabsorption of plasma protein lost to the urine by glomerular damage. Intratubular casts are markers of damage to the tubule cells themselves. Intramuscular injection of gentamycin sulphate resulted in thickening and sloughing of the glomerular epithelium in Channel catfish, Ictalurus punctatus (Rolf et al., 1986).

Vesilek et al. (2010) found that the caudal kidney of carp exposed to sub-lethal terbutryn showed cellular alterations such as destruction of the tubules in the caudal kidney. Fischer-Scherl et al. (1991) observed changes in renal corpuscules and tubules of rainbow trout after chronic exposure to atrazine.

McHugh et al. (2011) observed dilation of the glomerulus capillaries, vacuolation of the renal tubule and hyaline droplet degeneration in kidney of tigerfish, Hydrocynus vittatus from a DDT-affected area.

Schmidt-Posthaus et al. (2001) observed in brown trout exposed to polluted river water a higher prevalence and severity of tubulonephrosis, deposits of desquamating tubular cells, hyalinous casts in the tubules and peritubular fibroblast proliferation.

Camargo and Martinez (2007) found glomerular expansion and absence of the Bowman's space, and tubule cells with hypertrophied nucleus, tubule starting the regeneration process, occlusion of the tubular lumen and cloudy swelling degeneration in a Neotropical fish caged in an urban stream.

In their study Ptashynski and Klaverkamp (2002) observed histological alterations in the posterior kidney of white fish fed with high dose diets, indicating that kidney may be a target organ for nickel toxicity. In the control fish, the trunk kidney involved in excretory functions was formed by a large number of nephrons each having a renal corpuscle. The corpuscle was the proximal part of the tubule, which consists of two parts, a glomerulus and a capsule. The histopathological abnormalities in kidney of silver carp, Hypophthalmichthys molitrix were time dependent. The kidney of fish treated with nickel for 10 days, exhibited tubules with hyperplasia and hypertrophic nuclei and haemolysis of erythrocytes. In fish after 20 days of exposure the tubules were 
seen with cytoplasmolysis, karyolysis and vacuolization. At the end of 30 days treatment, ruptured cells, syncytical condition and pyknotic nuclei with aggregation of nuclei were seen due to the damage of plasma membrane. The glomerulus structure was disruptured, and the convoluted and uriniferous tubules are enlarged.

Athikesavan et al. (2006) also observed hypertrophy, hyperplasla, haemolysis, vacuolization, karyolysis, ruptured cell and pyknotic nuclei in the kidney of silver carp, Hypophthalmichthys molitrix exposed to sublethal concentrations of nickel after 30 days.

According to Weber et al. (2003) the occurrence of dilated tubules appears to be a consequence of dead and dying epithelial cells while a thickening of Bowman's capsule can arise as a result of fibrosis.

Pal et al. (2011) observed dilation of the glomerular capillaries and hemorrhage in the Bowman's space were noted in the renal corpuscles of exposure groups, necrosis of the tubular epithelium cells in the fish kidney exposed to dietary heavy oil. Similar structural changes were observed in brown trout, Salmo trutta f. fario and stone loach, Barbatula barbatula (Schwaiger et al., 1997) and in Astyanax altiparanae (Silva and Martinez, 2007) collected from polluted urban stream containing high amount of PAHs and other chemicals.

Glomerular lesions, shrinking of the glomerulus and enlargement of space inside Bowman's capsule, dwindling of the tubular lumen, degeneration and necrosis of renal tubules were observed in the kidney tissue of rainbow trout, Oncorhynchus mykiss after the exposure of 0.1 and $0.2 \mathrm{mg} / \mathrm{L}$ diazinon for 28 days period by Banaee et al. (2013). Gabriel et al. (2007) reported cellular hypertrophy, tubular degeneration, enlarged glomerulus and tubular necrosis in African catfish, Clarias gariepinus with a dosedependent relationship to fuel oil.

Silva and Martinez (2007) found that the histological alterations in the posterior kidney of Astyanax altiparanae from the investigated sites were in complete contrast to those from the reference site, in respect of the type, severity and number of lesions observed. Tissue changes in the reference fish were light, whereas the lesions found in fish from the studied stream were more severe and in some cases irreparable, such as necrosis of the tubule epithelial cells, reflecting the poor water quality of this urban stream.

In general, the morphological structure of fish kidneys is well-studied. However, on the basis of the observed literature we can say that in the histopathological studies, the kidneys are not as widely used as the gills and liver but yet the results are very useful in terms of water contamination and its effects on fish.

\section{Conclusions}

Overall, we can conclude that the histopathological alterations in target fish organs such as the gills, liver and kidneys have been successfully applied in ecotoxicological research and risk assessment programs in the last few decades. Even though, these biomarkers are non-specific, time-consuming (but relatively cheap) and require welltrained and knowledgeable experts, they provide accurate data on the effects of different contaminants which on the other hand, can signal for alterations at lower biological organization. We therefore, suggest that histopathology should be more often included in monitoring programs on contaminated aquatic systems, along with other biomarkers and chemical analyses of waters and sediments. 

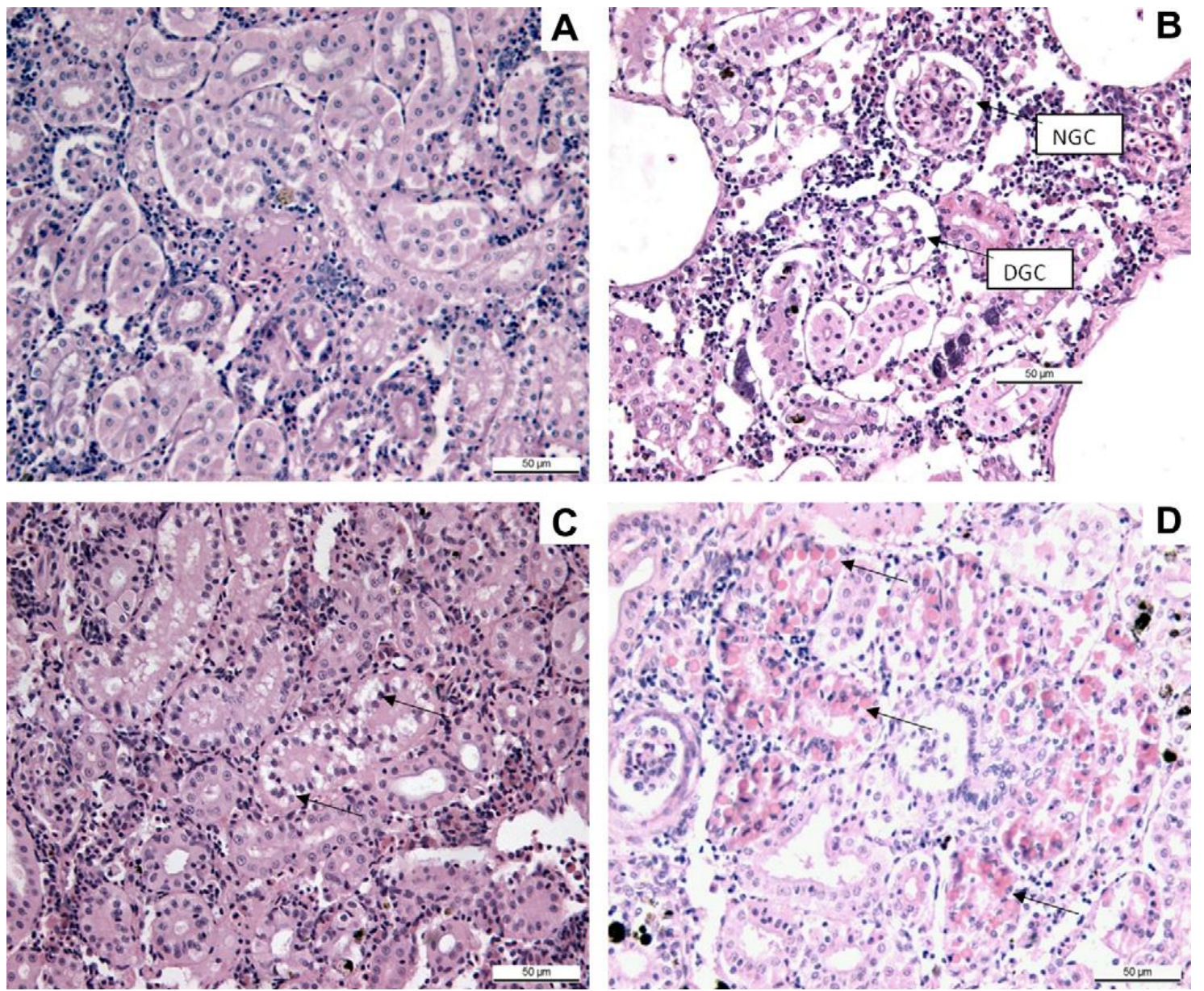

Figure 3. Micrographs of $H$. vittatus kidney sections $(5 \mu \mathrm{m})$ stained with $H \& E$ : (A) Normal

kidney; $(B)$ dilation of the glomerulus capillaries. Normal glomerulus represented by NGC and dilate glomerulus represented by DGC; $(C)$ vacuolation of the renal tubule (arrows); (D) hyaline droplet degeneration (arrows)(McHugh et al., 2011).

\section{REFERENCES}

[1] Ada, F.B., Ekpenyong, E., Ayotunde, E.O. (2012): Haematological, biological and behavioural changes in Oreochromis niloticus (Linn. 1757) juveniles exposed to paraquat herbicide. - Journal of Environmental Chemistry and Ecotoxicology 4(3): 64-74.

[2] Adeogun, A.O. (2012): Impact of industrial effluent on water quality and gill pathology of Clarias gariepinus from Alaro Stream, Ibadan, Southwest, Nigeria. - European Journal of Scientific Research 76 (1): 83-94.

[3] Ahmad, A., Pillai, K.K., Najmi, A.K., Ahmad, S.J., Pal, S.N., Balani, D.K. (2002): Evaluation of hepatoprotective potential of jigrine post-treatment against thioacetamide induced hepatic damage. - Journal of Ethnopharmacology 79(1): 35-41.

[4] Alazemi, B.M., Lewis, J.W., Andrews, E.B. (1996): Gill damage in the freshwater fish Gnathonemus Petersii (Family: Mormyridae) exposed to selected pollutants: an ultrastructural study. - Environmental Technology 17(3): 225-238.

[5] Alexopoulos, E., McCrohan, C. R., Powell, J.J., Jugdaohsingh, R., White, K.N. (2003): Bioavailability and toxicity of freshly neutralized aluminium to the freshwater crayfish Pacifastacus leniusculus. - Archives of Environmental Contamination and Toxicology 4(4): 509-514. 
[6] Al-Mamoori, A.M.J., Al-Zubaidy, F.M., Al-Rezzaq, A.J.A., Hadi, M.A., Yass, M.J. (2014): Biomarkers of chlorfos toxicity in common carp Cyprinus carpio. - Journal of Environmental Science, Toxicolology and Food Technology 8(1): 109-112.

[7] Arellano, J.M., Storch, V., Sarasquete, C. (1999): Histological changes and copper accumulation in liver and gills of the Senegales sole, Solea senegalensis. - Ecotoxicology and Environmental Safety 44(1): 62-72.

[8] Au, D.W.T. (2004): The application of histo-cytopathological biomarkers in marine pollution monitoring: a review. - Marine Pollution Bulletin 48(9-10): 817-834.

[9] Ayandiran, T.A., Fawole, O.O., Adewoye, S.O., Ogundiran, M.A. (2009): Bioconcentration of metals in the body muscle and gut of Clarias gariepinus exposed to sublethal concentrations of soap and detergent effluent. - Journal of Cell and Animal Biology 3: 113-118.

[10] Ayoola, S.O. (2009): Histopathological effects of glyphosate on juvenile African catfish (Clarias gariepinus). - Environmental Toxicology 24(2): 133-147.

[11] Banaee, M., Davoodi, M. H., Zoheiri, F. (2013): Histopathological changes induced by paraquat on some tissues of gourami fish (Trichogaster trichopterus). - Open Veterinary Journal 3(1): 36-42.

[12] Banaee, M., Sureda, A., Mirvagefei, A.R., Ahmadi, K. (2013): Histopathological alterations induced by diazinon in rainbow trout (Oncorhynchus mykiss). - International Journal of Environmental Research 7(3): 735-744.

[13] Begum, G. (2004): Carbofuran insecticide induced biochemical alterations in liver and muscle tissues of the fish Clarias batrachus (Linn) and recovery response. - Aquatic Toxicology 66: 83-92.

[14] Bernet, D., Schmidt, H., Meier, W., Burkhardt-Holm, P., Wahli, T. (2001): Histopathology in fish: proposal for a protocol to assess aquatic pollution. - Journal of Fish Diseases 22(1): 25-34.

[15] Bervoets, L., Blust, R. (2003): Metal concentrations in water, sediment and gudgeon (Gobio gobio) from a pollution gradient: relationship with fish condition factor. Environmental Pollution 126(1): 9-19.

[16] Boran, H., Altinok, I., Capkin, E. (2010): Histopathological changes induced by maneb and carbaryl on some tissues of rainbow trout, Oncorhynchus mykiss. - Tissue and Cell 42: 158-164.

[17] Braunbeck, T. (1993): Cytological alterations in isolated hepatocytes from rainbow trout (Oncorhynchus mykiss) exposed in vitro to 4-chloroaniline. - Aquatic Toxicolology 25: 83-110.

[18] Braunbeck, T., Görge, G., Storch, V., Roland, N. (1990a): Hepatic steatosis in zebra fish (Brachydanio rerio) induced by long-term exposure to $\gamma$-hexachlorocyclohexane. Ecotoxicology and Environmental Safety 19(3): 355-374.

[19] Braunbeck, T., Storch, V., Bresch, H. (1990b): Species-specific reaction of liver ultrastructure in zebrafish (Brachydanio rerio) and trout (Salmo gairdneri) after prolonged exposure to 4-chloroaniline. - Archives of Environmental Contamination and Toxicology 19: 405-418.

[20] Bury, N.R., Li, J., Flik, G., Lock, R.A.C., Wendelaar-Bonga, S.E. (1998): Cortisol protects against copper induced necrosis and promotes apoptosis in fish gill chloride cells in vitro. - Aquatic Toxicology 40: 193-202.

[21] Butchiram, M. S., Tilak, K. S., Raju, P. W. (2009): Studies on histopathological changes in the gill, liver and kidney of Channa punctatus (Bloch) exposed to alachlor. - Journal of Environmental Biology, 30(2): 303-306.

[22] Camargo, M.M.P., Martinez, C.B.R. (2007): Histopathology of gills, kidney and liver of a Neotropical fish caged in an urban stream. - Neotropical Ichthyology 5(3): 327-336.

[23] Carpene, E., Vasak, M. (1989): Hepatic metallothioneins from goldfish (Carassius auratus). - Comparative Biochemistry and Physiology 92, 463-468. 
[24] Carrola, J., Fontaínhas-Fernandes, A., Matos, P., Rocha, E. (2009): Liver histopathology in brown trout (Salmo trutta f. fario) from the Tinhela River, subjected to mine drainage from the abandoned Jales mine (Portugal). - Bulletin of Environmental Contamination and Toxicology 83(1): 35-41.

[25] Carvalho-Neta, R. N. F., Sousa, D. B. P., Almeida, Z. S., Santos, D. M. S. (2014): A histopathological and biometric comparison between catfish (Pisces Ariidae) from a harbor and a protected area Brazil. - Aquatic Biosystems 10: 1-10.

[26] Cengiz, E.I. (2006): Gill and kidney histopathology in the freshwater fish Cyprinus carpio after acute exposure to deltamethrin. - Environmental Toxicology and Pharmacology 22(2): 200-204.

[27] Cengiz, E.I., Ünlü, E. (2002): Histopathological changes in the gills of mosquitofish, Gambusia affinis exposed to endosulfan. - Bulletin of Environmental Contamination and Toxicology 68(2): 290-296.

[28] Cengiz, E.I., Unlu, E. (2006): Sublethal effects of commercial deltamethrin on the structure of the gill, liver and gut tissues of mosquitofish, Gambusia affinis: A microscopic study. - Environmental Toxicology and Pharmacology 21(3): 246-253.

[29] Chamarthi, R.R., Bangeppagari, M., Gooty, J. M., Mandala, S., Tirado, J. O., Marigoudar S.R. (2014): Histopathological alterations in the gill, liver and brain of Cyprinus carpio on exposure to quinalphos. - American Journal of Life Sciences 2(4): 211-216.

[30] Dang, Z.C., Berntssen, M.H.G., Lundebye, A.K., Flika, G., Wendelaar Bonga, S.E., Lock, R.A.C. (2001): Metallothionein and cortisol receptor expression in gills of Atlantic salmon, Salmo salar, exposed to dietary cadmium. - Aquatic Toxicology 53(2): 91-101.

[31] De Boeck, G., Smolders, R., Blust, R. (2010): Copper toxicity in gibel carp Carassius auratus gibelio: Importance of sodium and glycogen. - Comparative Biochemistry and Physiology 152: 332-337.

[32] De Boeck, G., Vlaeminck, A., Balm, P.H., Lock, R.A., De Wachter, B., Blust, R. (2001): Morphological and metabolic changes in common carp, Cyprinus carpio, during shortterm copper exposure: interactions between $\mathrm{Cu}^{2+}$ and plasma cortisol elevation. Environmental Toxicology and Chemistry 20: 374-381.

[33] de La Torre, F.R., Ferrari, L., Salibián, A. (2005): Biomarkers of a native fsh species (Cnesterodon decemmaculatus) application to the water toxicity assessment of a periurban polluted river of Argentina. - Chemosphere, 59(4): 577-583.

[34] Devi, Y., Mishra, A. (2013): Study of behavioural and morphological anomalies of fry fish of fresh water teleost, Channa punctatus under chlorpyrifos intoxication. International Journal of Pharmacological and Biological Sciences Part B 4: 865-874.

[35] Do Carmo Langiano, V., Martinez, C.B.R. (2008): Toxicity and effects of a glyphosatebased herbicide on the Neotropical fish, Prochilodus lineatus. - Comparative Biochemistry and Physiology 147: 222-231.

[36] Doughtie, D.G., Rao, K.R. (1983): Ultrastructural and histological study of degenerative changes leading to black gills in grass shrimp exposed to a dithiocarbamate biocide. Journal of Invertebrate Pathology 41(1): 33-50.

[37] El-Serafy, S.S, Abdel-Hameid, N-A.H., El-Daly, A.A. (2009): Histological and histochemical alterations induced by phenol exposure in Oreochromis aureus (Steindachner, 1864) juveniles. - Egyptian Journal of Aquatic Biology and Fisheries 13(2): 151-172.

[38] Evans, D.H., Piermarini, P.M., Choe, K.P. (2005): The multifunctional fish gill: dominant site of gas exchange, osmoregulation, acid-base regulation, and excretion of nitrogenous waste. - Physiological Reviews 85: 97-177.

[39] Fanta, E., Rios, F.S., Romão, S., Vianna, A.C., Freiberger, S. (2003): Histopathology of the fish Corydoras paleatus contaminated with sublethal levels of organophosphorus in water and food. - Ecotoxicology and Environmental Safety 54(2): 119-130.

[40] Feist, S.W., Lang, T., Stentiford, G.D., Köhler, A. (2004): Biological effects of contaminants: use of liver pathology of the European flatfish dab (Limanda limanda L.) 
and flounder (Platichthys flesus L.) for monitoring. ICES Techniques in Marine Environmental Sciences No. 38, ICES, Copenhagen.

[41] Fernandes, C., Fontaínhas-Fernandes, A., Rocha, E., Salgado, M.A. (2008): Monitoring pollution in Esmoriz-Paramos lagoon, Portugal: liver histological and biochemical effects in Liza saliens. - Environmental Monitoring and Assessment 145: 315-322.

[42] Ferreira, M., Moradas-Ferreira, P., Reis-Henriques, M.A. (2005): Oxidative stress biomarkers in two resident species, mullet (Mugil cephalus) and flouder (Platichthys flesus), from a polluted site in River Douro estuary, Portugal. - Aquatic toxicology 71: $39-48$.

[43] Figueiredo-Fernandes, A., Ferreira-Cardoso, J.V., Garcia-Santos, S., Monteiro, S.M., Carrola, J., Matos, P., Fontaínhas-Fernandes, A. (2007): Histopathological changes in liver and gill epithelium of Nile tilapia, Oreochromis niloticus, exposed to waterborne copper. - Pesquisa Veterinária Brasileira 27(3): 103-109.

[44] Figueiredo-Fernandes, A., Fontainhas-Fernandes, A., Monteiro, R., Reis-Henriques, M. A., Rocha E. (2006): Effects of the fungicide mancozeb on liver structure of Nile tilapia, Oreochromis niloticus - assessment and quantification of induced cytological changes using qualitative histopathology and the stereological point-sampled intercept method. Bulletin of Environmental Contamination and Toxicology 76: 249-255.

[45] Flores-Lopes, F.I, Thomaz, AT. (2011): Histopathologic alterations observed in fish gills as a tool in environmental monitoring. - Brazilian Journal of Biology 71(1): 179-188.

[46] Fontaínhas-Fernandes, A., Luzio, A., Garcia-Santos, S., Carrola, J., Monteiro, S. (2008): Gill histopathological alterations in Nile tilapia, Oreochromis niloticus exposed to treated sewage Water. - Brazilian Archives of Biology and Technology 51(5): 1057-1063.

[47] Fossi, M.C. (1998): Biomarkers as diagnostic and prognostic tools for wildlife risk assessment: integrating endocrine-Disrupting chemicals. - Toxicology and Industrial Health 14(1-2): 291-309.

[48] Fossi, M.C., Marsili, L. (1997): The use of non destructive biomarkers in the study of marine mammals. - Biomarkers 2(4): 205-216.

[49] Gaafar, A.Y., El-Manakhly, E.M., Soliman, M.K., Soufy, H., Zaki, M.S., Mohamed S. G., Hassan, S.M. (2010): Some pathological, biochemical and hematological investigations on Nile tilapia (Oreochromis niloticus) following chronic exposure to edifenphos pesticide. - Journal of American Science 6(10): 542-551.

[50] Garcia-Santos, S., Fontaínhas-Fernandes, A., Wilson, J.M. (2006): Cadmium tolerance in the Nile tilapia (Oreochromis niloticus) following acute exposure: Assessment of some ionoregulatory parameters. - Environmental Toxicology 21(6): 33-46.

[51] Georgieva, E., Stoyanova, S., Velcheva, I., Vasileva, T., Bivolarski, V., Iliev, I., Yancheva, V. (2014): Metal effects on histological and biochemical parameters of common rudd (Scardinius erythrophthalmus L.). - Archives of Polish Fisheries 22: 197206.

[52] Georgieva, E., Stoyanova, S., Velcheva, I., Yancheva, V. (2015): Histopathological alterations in common carp (Cyprinus carpio L.) gills caused by thiamethoxam. Brazilian Archives of Biology and Technology 57(6): 991-996.

[53] Gernhöfer, M., Pawert, M., Schramm, M., Müller, E., Triebskorn, R. (2001): Ultrastructural biomarkers as tools to characterize the health status of fish in contaminated streams. - Journal of Aquatic Ecosystem Stress and Recovery 8(3-4): 241260.

[54] Greenfield, B.K., Teh, S.J., Ross, J.R.M., Hunt, J., Zhang, G.H., Davis, J.A., Ichikawa, G., Crane, D., Hung, S.S.O., Deng, D.F., Teh, F.-C., Green, P.G. (2008): Contaminant concentrations and histopathological effects in Sacramento splittail (Pogonichthys macrolepidotus). - Archives of Environmental Contamination and Toxicology 55(2): 270281.

[55] Grund, S., Keiter, S., Bottcher, M., Seitz, N., Wurm, K., Manz, W., Hollert, H.T.B. (2010): Assessment of fish health status in the Upper Danube River by investigation of 
ultrastructural alterations in the liver of barbel Barbus barbus. - Diseases of Aquatic Organisms 88: 235-248.

[56] Gultekin, F., Ozturk, M., Akdogan, M. (2000): The effect of organophosphate insecticide chlorpyrifosethyl on lipid peroxidation and antioxidant enzymes (in vitro). - Archives of Toxicology 74: 533-538.

[57] Haaparanta, A., Valtonen, E.T., Hoffmann, R.W. (1997) : Gill amonalies of perch and roach of four lakes differing in water quality. - Journal of Fish Biology 50: 575-591.

[58] Hasan, Z., Ghayyur, S., Hassan, Z.U., Rafique S. (2014): Histomorphometric and hematological profile of grass carp (Ctenopharyngodon idella) during acute endosulfan toxicity. - Pakistan Veterinary Journal 35(1): 23-27.

[59] Hassaninezhad, L., Safahieh, A.R., Salamat, N., Savari, A., Majd, N.E. (2014): Assessment of gill pathological responses in the tropical fish yellowfin seabream of Persian Gulf under mercury exposure. - Toxicology Reports 1: 621-628.

[60] Heier, L.S., Lien, I.B., Strømseng, A.E., Ljønes, M., Rosseland, B.O., Tollefsen, K.-E., Salbu, B. (2009): Speciation of lead, copper, zinc and antimony in water draining a shooting range - Time dependant metal accumulation and biomarker responses in brown trout (Salmo trutta L.). - Science of the Total Environment 407(13): 4047-4055.

[61] Hermoso, V., Clavero, M., Blanco-Garrido, F., Prenda, J. (2010): Assessing the ecological status in species-poor systems: A fish-based index for Mediterranean Rivers (Guadiana River, SW Spain). - Ecological Indicators 10(6): 1152-1161.

[62] Hinton, D.E. (1994): Cells, cellular responses, and their markers on chronic toxicity of fishes. In: Malins, D.C., Ostrander, G.K. (Eds.), Aquatic Toxicology: Molecular, Biochemical, and Cellular Perspectives. Lewis Publishers, Boca Raton, pp. 207-239.

[63] Hinton, D.E., Baumann, P.C., Gardner, G.R., Hawkins, W.E., Hendricks, J.D., Murchelano, R.A., Okihiro, M.S. (1992): Histopathologic biomarkers. Biochemical, physiological, and histological markers of anthropogenic stress. In: Biomarkers. Lewis Publishers, Boca Raton, pp. 155-209.

[64] Hinton, D.E., Lauren, D.J. (1990): Liver structural alterations accompanying chronic toxicity in fishes: potential biomarkers of exposure. In: McCarthy, J.F., Shugart, L.R. (Eds.), Biomakers of Environmental Contamination. Lewis Publishers, Boca Raton, FL, pp. 17-57.

[65] Hinton, D.E., Segner, H., Braunbeck, T. (2001): Toxic responses of the liver. In: Schlenk, D., Bensen, W.H. (Eds.), Organs. In: Toxicity in Marine and Freshwater Teleosts, vol. 1. Taylor \& Francis, London, pp. 224-268.

[66] Hued, A.C., Oberhofer, S., de los Ángeles Bistoni, M. (2012): Exposure to a commercial glyphosate formulation (Roundup ${ }^{\circledR}$ ) alters normal gill and liver histology and affects male sexual activity of Jenynsia multidentata (Anablepidae, Cyprinodontiformes). Archives of Environmental Contamination and Toxicology 62(1): 107-117.

[67] Hwang, P.P.,Tsai, Y.N. (1993): Effects of arsenic on osmoregulation in the tilapia Oreochromis mossambicus reared in seawater. - Marine Biology 117: 551-558.

[68] Johnson, L.L., Stehr, C.M., Olson, O.P., Myers, M.S., Plerce, S.M., Wigren, C.A., McCain, B.B., Varanasi, U. (1993): Chemical contaminants and hepatic lesions in winter flounder (Pleuronectes americanus) from the northeast coast of the United States. Environmental Science and Technology 27: 2759-2771.

[69] Jörundsdóttir, H., Halldorsson, T.I., Gunnlaugsdottir, H. (2014): PFAAs in fish and other seafood products from Icelandic waters. - Journal of Environmental and Public Health 1: $1-6$.

[70] Karan, V., Vitorovic, S., Tutundzic, V., Poleksic, V. (1998): Functional enzymes activity and gill histology of carp after copper sulfate exposure and recovery. - Ecotoxicology and Environmental Safety 40: 49-55.

[71] Karlsson-Norggren, L., Dickson, W., Ljungberg, O., Runn, P. (1986): Acid water and aluminium exposure: gill lesions and aluminium accumulation in farmed, brown trout, Salmo trutta L. - Journal of Fish Diseases 9: 1-9. 
[72] Kroglund, F., Rosseland, B.O., Teien, H.-C., Salbu, B., Kristensen, T., Finstad, B. (2008): Water quality limits for Atlantic salmon (Salmo salar L.) exposed to short term reductions in $\mathrm{pH}$ and increased aluminum simulating episodes. - Hydrology and Earth System Sciences 12: 491-507.

[73] Lang, T. (2002): Fish disease surveys in environmental monitoring: the role of ICES. ICES Marine Science Symposia 215: 202-212.

[74] Lang, T., Wosniok, W., Baršienèc, J., Broeg, K., Kopecka, J., Parkkonen, J. (2006): Liver histopathology in Baltic flounder (Platichthys flesus) as indicator of biological effects of contaminants. - Marine Pollution Bulletin 53: 488-496.

[75] Laurèn, D.J., McDonald, D.G. (1985): Effects of copper on branchial ionoregulation in the rainbow trout, Salmo gairdneri Richardson: modulation by water hardness and $\mathrm{pH}$. Journal of Comparative Physiology 155: 635-644.

[76] Laurent, P., Perry, S.F. (1991): Environmental effects on fish gill morphology. Physiological Zoology 53: 4-25.

[77] López-Barea, J. (1995): Biomarkers in Ecotoxicology: an Overview. - Archives of Toxicology 17: 57-79.

[78] Lushchak, V. I. (2011): Environmentally induced oxidative stress in aquatic animals. Aquatic Toxicology 101(1):13-30.

[79] Madureira, T.V., Rocha, M.J., Cruzeiro, C., Rodrigues, I., Monteiro, R.A.F., Rocha, E.. (2012): The toxicity potential of pharmaceuticals found in the Douro River estuary (Portugal): Evaluation of impacts on fish liver, by histopathology, stereology, vitellogenin and CYP1A immunohistochemistry, after sub-acute exposures of the zebrafish model. - Environmental Toxicology and Pharmacology 34(1): 34-45.

[80] Majnoni, F., Rezaei, M., Mansouri, B., Hamidian, A.H. (2013): Metal concentrations in tissues of common carp, Cyprinus carpio, and silver carp, Hypophthalmichthys molitrix from the Zarivar Wetland in Western Iran. - Archives of Polish Fisheries 21(1): 11-18.

[81] Mallatt, J. (1985): Fish gill structural changes induced by toxicants and other irritants: a statistical review. - Canadian Journal of Fisheries and Aquatic Science 42: 630-648.

[82] Marchand, M.J., van Dyk, J.C., Pieterse, G.M., Barnhoorn, I.E.J., Bornman, M.S. (2009): Histopathological alterations in the liver of the sharptooth catfish Clarias gariepinus from polluted aquatic systems in South Africa. - Environmental Toxicology 24(2): 133-147.

[83] Martinez, C.B.R., Nagae, M.Y., Zaia, C.T.B.V., Zaia, D.A.M. (2004): Morphological and physiological acute effects of lead in the neotropical fish, Prochilodus lineatus. Brazilian Journal of Biology 64(4): 797-807.

[84] Marty, G.D., Hoffmann, A., Okihiro, M.S., Hepler, K., Hanes, D. (2003): Retrospective analysis: bile hydrocarbons and histopathology of demersal rockfish in Prince William Sound, Alaska, after the Exxon Valdez oil spill. - Marine Environmental Research 56(5): 569-584.

[85] Matos, P., Fontaínhas-Fernandes, A., Peixoto, F., Carrola, J., Rocha, E. (2007): Biochemical and histological hepatic changes of Nile tilapia Oreochromis niloticus exposed to carbaryl. - Pesticide Biochemistry and Physiology 89(1): 73-80.

[86] Mazon, A.F., Monteiro, E.A.S., Pinheiro, G.H.D., Fernadez, M.N. (2002): Hematological and physiological changes induced by short-term exposure to copper in the freshwater fish, Prochilodus scrofa. - Brazilian Journal of Biology 62(4a): 621-631.

[87] McHugh, K.J., Smit, N.J., Van Vuren, J.H.J., van Dyk, J.C., Bervoets, L., Covaci, A., Wepener, V. (2011): A histology-based fish health assessment of the tigerfish, Hydrocynus vittatus from a DDT-affected area. - Physics and Chemistry of the Earth 36(14-15): 895-904.

[88] Mela, M., Randi, M.A.F., Ventur, D.F., Carvalho, C.E.V., Pelletier, E., Oliveira Ribeiro, C.A. (2007): Effects of dietary methylmercury on liver and kidney histology in the neotropical fish Hoplias malabaricus. - Ecotoxicology and Environmental Safety 68(3): 426-435. 
[89] Mishra, A.K., Mohanty B. (2008): Acute toxicity impacts of hexavalent chromium on behavior and histopathology of gill, kidney and liver of the freshwater fish, Channa punctatus (Bloch). - Environmental Toxicology and Pharmacology 26(2): 136-141.

[90] Mohamed, F.A.S. (2009): Histopathological studies on Tilapia zillii and Solea vulgaris from Lake Qarun, Egypt. - World Journal of Fish and Marine Sciences 1(1): 29-39.

[91] Moiseenko, T.I., Kudryavtseva, L.P. Gashkina, N.A. (2005): Assessment of the geochemical background and anthropogenic load by bioaccumulation of microelements in Fish. - Water Resources 32(6): 640-652.

[92] Monteiro, S.M., Mancera, J.M., Fontaínhas-Fernandes, A., Sousa, M. (2005): Copper induced alterations of biochemical parameters in the gill and plasma of Oreochromis niloticus. - Comparative Biochemistry and Physiology 141:375-383.

[93] Monteiro, S.M., Quintaneiro, C., Morgado, F., Soares, A.M.V.M., Guilhermino, L. (2005): Characterization of the cholinestarases presence of head tissues of the estuarine fish Pomatoschtistus microps: application to biomonitoring. Ecotoxicology and Environmental Safety 62: 341-347.

[94] Monteiro, S.M., Rocha, E., Fontainhas-Fernandes A., Sousa, M. (2008): Quantitative histopathology of Oreochromis niloticus gills after copper exposure. - Journal of Fish Biology, 73(6): 1376-1392.

[95] Moon, T.W., Walsh, P.J., Mommsen, T.P. (1985): Fish hepatocytes: A model metabolic system. - Canadian Journal of Fisheries and Aquatic Sciences 42: 1772-1782.

[96] Moore M.J., Smolowitz R.M., Stegeman J.J. (1997): Stages of hydropic vacuolation in the liver of winter flounder Pleuronectes americanus from a chemically contaminated site. - Diseases of Aquatic Organisms $31: 19-28$.

[97] Nero, V., Farwell, A., Lee, L. E., Van Meer, T., MacKinnon, M.D., Dixon, D.G. (2006): The effects of salinity on naphthenic acid toxicity to yellow perch: gill and liver histopathology. - Ecotoxicology and Environmental Safety 65(2): 252-264.

[98] Nero, V., Farwell, A., Lister, A., Van Der Kraak, G., Lee, L.E.J., Van Meer, T., MacKinnon, M.D., Dixon, D.G. (2006): Gill and liver histopathological changes in yellow perch (Perca flavescens) and goldfish (Carassius auratus) exposed to oil sands process-affected water. - Ecotoxicology and Environmental Safety 63(3): 365-377.

[99] Nigro, M., Falleni, A., Del Barga, I., Scarcelli, V., Lucchesi, P., Regoli, F., Frenzilli, G. (2006): Cellular biomarkers for monitoring estuarine environments: transplanted versus native mussels. - Aquatic Toxicology 77: 339-347.

[100] Nowak, B.F., Deavin, J.G., Sarjito, Munday, B.L. (1992): Scanning electron microscopy in aquatic toxicology. - Journal of Computer-Assisted Microscopy 4: 241-246.

[101] NRC (National Research Council). (1987): Biological markers in environmental health research. - Environmental Health and Perspective 74: 3-9.

[102] Nunes, B., Campos, J.C., Gomes, R., Braga, M.R., Ramos, A.S., Antunes, S.C., Correia, A.T. (2015): Ecotoxicological effects of salicylic acid in the freshwater fish Salmo trutta fario: antioxidant mechanisms and histological alterations. - Environmental Science and Pollution Research 22(1): 667-678.

[103] Ogundiran, M.A., Fawole, O.O., Adewoye, S.O., Ayandiran, T.A. (2009): Pathologic lesions in the gills of Clarias gariepinus exposed to sublethal concentrations of soap and detergent effluents. - Animal Biology 3(5): 78-82.

[104] Olarinmoye, O., Taiwo, V., Clarke, E., Kumolu-Johnson, C., Aderinola, O., Adekunbi, F. (2009): Hepatic pathologies in the brackish water catfish (Chrysichthys nigrodigitatus) from contaminated locations of the lagos lagoon complex. - Applied Ecology and Environmental Research 7(3): 277-286.

[105] Oliveira Ribeiro, C.A., Filipack, F., Mela, M., Silva, P.H., Randi, M.A.F., Costa, J.R.A., Pelletier, E. (2006): Hematological findings in neotropical fish Hoplias malabaricus exposed to subchronic and dietary doses of methylmercury, inorganic lead and tributyltin chloride. - Environmental Research 101: 74-80. 
[106] Oliveira Ribeiro, C.A., Pelletier, E., Pfeiffer, W.C., Rouleau, C. 2000. Comparative uptake, bioaccumulation, and gill damages of inorganic mercury in tropical and Nordic freshwater fish. - Environmental Research 83: 286-292.

[107] Oliveira Ribeiro, C.A., Vollaire, Y., Sanchez-Chardi, A., Roche, H. (2005): Bioaccumulation and the effects of organochlorine pesticides, PAH and heavy metals in the eel (Anguilla anguilla) at the Camargue Nature Reserve, France. - Aquatic Toxicology 74: 53-69.

[108] Olsvik, P.A., Gundersen, P., Andersen, R.A., Zachariassen, K.E. (2001): Metal accumulation and metallothionein in brown trout, Salmo trutta, from two Norwegian rivers differently contaminated with $\mathrm{Cd}, \mathrm{Cu}$ and $\mathrm{Zn}$. - Comparative Biochemistry and Physiology 128(2): 189-201.

[109] Olufayo, M.O., Alade, O.H. (2012): Acute toxicity and histological changes in gills, liver and kidney of catfish, Heterobranchus bidorsalis exposed to cypermethrin concentration. - African Journal of Agricultural Research 7(31): 4453-4459.

[110] Olurin, K., Olojo, E., Mbaka, G., Akindele, A. (2006): Histopathological responses of the gill and liver tissues of Clarias gariepinus fingerlings to the herbicide, glyphosate. African Journal of Biotechnology 5: 2480-2487.

[111] Ondarza, P.M., Gonzalez, M., Fillmann, G., Miglioranza, K.S.B. (2011): Polybrominated diphenyl ethers and organochlorine compound levels in brown trout (Salmo trutta) from Andean Patagonia, Argentina. - Chemosphere 83: 1597-1602.

[112] Ondarza, P.M., Miglioranza, K.S.B., Gonzalez, M., Shimabukuro, V.M., Aizpún, J.E., Moreno, V.J. (2010): Organochlorine compounds in common carp (Cyprinus carpio) from Patagonia Argentina. - Journal of the Brazilian Society of Ecotoxicology 5: 41-47.

[113] Oropeca, A.L., Garcia, J.P., Gomez, G.L., Roncero, C.V., Soler, R.F. 2005. Gill modifications in the freshwater fish Cyprinus carpio after subchronic exposure to simazine. - Bulletin of Environmental Contamination and Toxicology 74: 785-792.

[114] Ortiz, J.B., González De Canales, M.L., Sarasquete, C. (2003): Histopathological changes induced by lindane $(\gamma-\mathrm{HCH})$ in various organs of fishes. - Scientia Marina 67(1): 53-61.

[115] Paithane, K.T., Sonawane, D.L., Bhandare, R.Y., More, P.R. (2012): Histophatological changes due to induced dimethoate in the liver of freshwater fish Channa punctatus from river Shivana, Aurangabad (M.S) India. - The Ecoscan Special Issue 1: 213-217.

[116] Pane, E.F., Haque, A., Wood C.M. (2004): Mechanistic analysis of acute, Ni-induced respiratory toxicity in the rainbow trout (Oncorhynchus mykiss): an exclusively branchial phenomenon. - Aquatic Toxicology 69: 11-24.

[117] Paris-Palacios, S., Biagianti-Risbourg, S., Vernet, G. (2000): Biochemical and (ultra)structural hepatic perturbations of Brachydanio rerio (Teleostei, Cyprinidae) exposed to two sublethal concentrations of copper sulfate. - Aquatic Toxicology 50(1-2): 109-124.

[118] Pathan, T.S., Sonawane, D.L., Khillare, Y.K. (2009a): Toxicity and behavioural changes in freshwater fish Rasbora daniconus exposed to tannery mill effluent. - Botany Research International 2(4): 263-266.

[119] Pathan, T.S., Thete, P.B., Shinde, S.E., Sonawane, D.L., Khillare, Y.K. (2009b): Histochemical changes in the liver of freshwater fish, Rasbora daniconius, exposed to paper mill effluent. - Emirates Journal of Food and Agriculture 21(2): 71-78.

[120] Pereira, S., Pinto, A.L., Cortes, R., Fontaínhas-Fernandes, A., Coimbra, A.M., Monteiro, S.M. (2013): Gill histopathological and oxidative stress evaluation in native fish captured in Portuguese northwestern rivers. - Ecotoxicology and Environmental Safety 90(1): 157166.

[121] Perry, S.F. (1997): The chloride cell: Structure and function in the gills of freshwater fishes. - Annual Reviews of Physiology 59: 325-347.

[122] Perry, S.F., Laurent, P. (1993): Environmental effects on fish gill structure and function. Fish Ecophysiology 9: 231-264. 
[123] Pinto, A., Varandas, S., Coimbra, A., Carrola, J., Fontaínhas-Fernandes, A. (2009): Mullet and gudgeon liver histopathology and macroinvertebrate indexes and metrics upstream and downstream from a wastewater treatment plant (Febros River-Portugal). Environmental Monitoring and Assessment 169, 569-585.

[124] Playle, R.C. (1998): Modelling metal interactions at fish gills. - Science of the Total Environment 219 (2-3): 147-163.

[125] Playle, R.C., Dixon, D.G., Burnison, K. (1993): Copper and cadmium binding to fish gills: estimates of metal-gill stability constants and modelling of metal accumulation. Canadian Journal of Fisheries and Aquatic Sciences 50(12): 2678-2687.

[126] Pokorska K., Protasowicki M., Bernat K., Kucharczyk M. (2012): Content of metals in flounder, Platichthys flesus L., and Baltic herring, Clupea harengus membras L., from the southern Baltic Sea. - Archives of Polish Fisheries 20(1): 51-53.

[127] Poleksić, V., Karan, V. (1999): Effects of trifluralin on carp: biochemical and histological evaluation. - Ecotoxicology and Environmental Safty 43: 213-221.

[128] Pourang N. (1995): Heavy metal bioaccumulation in different tissues of two fish species with regards to their feeding habits and trophic levels. - Environmental Monitoring and Assessment 35(3): 207-219.

[129] Powers, D. A. (1989): Fish as model systems. - Science 246(4928): 352-3588.

[130] Rajeshkumar, S., Munuswamy, N. (2011): Impact of metals on histopathology and expression of HSP 70 in different tissues of Milk fish (Chanos chanos) of Kaattuppalli Island, South East Coast, India. - Chemosphere 83(4): 415-421.

[131] Ramírez-Duarte, F.W., Rondón-Barragán, I.S., Eslava-Mocha, P.R. (2008): Acute toxicity and histopathological alterations of Roundup ${ }^{\circledR}$ herbicide on "cachama blanca" (Piaractus brachypomus). - Pesqisa Veterinária Brasiliera 28(11):547-554.

[132] Randi, A.S., Monserrat, J.M., Rodriguez, E.M., Romano, L.A. (1996): Histopathological effects of cadmium on the gills of the freshwater fish, Macropsobrycon uruguayanae Eigenmann (Pisces, Atheinidae). - Journal of Fish Diseases 19: 311-322.

[133] Rao, J.V., Begum, G., Sridhar, V., Reddy, N.C. (2005): Sublethal effects of monocrotophos onlocomotor behavior and gill architecture of the mosquito fish, Gambusia affinis. - Journal of Environmental Science and Health 40: 813-825.

[134] Rao, J.V., Shilpanjali, D., Kavitha, P., Madhavendra, S.S. (2003): Toxic effects of profenofos ontissue acetylcholinesterase and gill morphology in aeuryhaline fish, Oreochromis mossambicus. - Archives of Toxicology 77(4): 227-232.

[135] Reid, S.D., McDonal, D.G. (2011): Metal binding activity of the gills of rainbow trout (Oncorhynchus mykiss). - Canadian Journal of Fisheries and Aquatic Sciences 48(6): 1061-1068.

[136] Reid, S.D., McDonald, D.G. (1988): Effects of cadmium, copper and low pH on ion fluxes in the rainbow trout, Salmo gairdneri. - Canadian Journal of Fisheries and Aquatic Sciences 45: 244-253.

[137] Rosety-Rodríguez, M., Ordoñez, F.J., Rosety, J.M., Rosety, I., Ribelles, A., Carrasco, C. (2002): Morpho-histochemical changes in the gills of turbot, Scophthalmus maximus L., induced by sodium dodecyl sulfate. - Ecotoxicology and Environmental Safety 51: 223228.

[138] Rosseland, B.O., Rognerud, S., Collen, P., Grimalt, J.O., Vives, I., Massabuau, J.-C., Lackner, R., Hofer, R., Raddum, G.G., Fjellheim, A., Harriman, R., Piña, B. (2007): Brown trout in Lochnagar: Population and contamination by metals and organic micropollutants. - Developments in Paleoenvironmental Research 12: 253-285.

[139] Saber, T.H. 2011. Histological adaptation to thermal changes in gills of common carp fishes Cyprinus carpio L. - Rafidain Journal of Science 22: 46-55.

[140] Salamat, N., Zarie, M. (2012): Using of fish pathological alterations to assess aquatic pollution: A Review. - World Journal of Fish and Marine Sciences 4(3): 223-231. 
[141] Santhakumar, M., Balaji, M., Ramudu, K. (2001): Gill lesions in the perch, Anabas testudineus, exposed to monocrotophos. - Journal of Environmental Biololgy 22 (2): 8790.

[142] Scardi, M., Cataudella, S., Di Dato, P., Fresi, E., Tancioni, L. (2008): An expert system based on fish assemblages for evaluating the ecological quality of streams and rivers. Ecological Informatics 3(1): 55-63.

[143] Schlenk, D. (1999): Necessity of defining biomarkers for use in ecological risk assessments. - Marine Pollution Bulletin 39: 48-53.

[144] Schramm, M., Muller, E., Triebskorn, R. (1998): Brown trout Salmo trutta f. fario liver ultrastructure as a biomarker for assessment of small stream pollution. - Biomarkers 3(2): 93-108.

[145] Schwaiger, J., Ferling, H., Mallow, U., Wintermayr, H., Negele, R.D. (2004): Toxic effects of the non-steroidal anti-inflammatory drug diclofenac. Part I. Histopathological alterations and bioaccumulation in rainbow trout. - Aquatic Toxicology 68: 141-150.

[146] Sekabira, K., Oryem Origa, H., Basamba, T. A., Mutumba, G., Kakudidi, E. (2010): Assessment of heavy metal pollution in the urban stream sediments and its tributaries. International Journal of Environmental Sciences and Technology 7(3): 435-446.

[147] Simonato, J.D., Guedes, C.L.B., Martinez, C.B.R. (2008): Biochemical, physiological, and histological changes in the neotropical fish Prochilodus lineatus exposed to diesel oil. - Ecotoxicology and Environmental Safety 69(1): 112-120.

[148] Simpson, M.G., Parry, M., Kleinkauf, A., Swarbreck, D., Walker, P., Leah, R.T. (2000): Pathology of the liver, kidney and gonad of flounder (Platichthys flesus) from a UK estuary impacted by endocrine disrupting chemicals. - Marine Environmental Research 50(1-5): 283-287.

[149] Singh, R.N. (2014): Effects of dimethoate (EC 30\%) on gill morphology, oxygen consumption and serum electrolyte levels of common carp, Cyprinus Carpio (Linn). Internatonal Journal of Environmental Science Research 2(6): 192-198.

[150] Sloman, K.A. (2007): Effects of trace metals on salmonid fish: The role of social hierarchies. - Applied Animal Behaviour Science 104(3-4): 326-345.

[151] Sola, F., Isaia, J., Masoni, A. (1995): Effects of copper on gill structure and transport function in the rainbow trout, Oncorhynchus mykiss. - Journal of Applied Toxicology 15: 391-398.

[152] Sousa, D.B.P., Almeida, Z.S., Carvalho-Neta, R.N.F. (2013a): Histology biomarkers in two estuarine catfish species from the Maranhense Coast. - Arquivo Brasileiro de Medicina Veterinária e Zootecnia 65(2): 369-376.

[153] Sousa, D.B.P., Almeida, Z.S., Carvalho-Neta, R.N.F. (2013b): Integrated analysis of two biomarkers in Sciades herzbergii (Ariidae, Siluriformes), to assess the environmental impact at São Marcos? - Latin American Journal of Aquatic Research, 45: 305-312.

[154] Stehr, C.M., Johnson, L.L., Myers, M.S. (1998): Hydropic vacuolation in the liver of three species of fish from the U.S. West Coast: lesion description and risk assessment associated with contaminant exposure. - Diseases of aquatic organisms, 32: 119-135.

[155] Stentiford, G.D, Longshaw, M., Lyons, B.P., Jones, G., Green, M., Feist, S.W. (2003): Histopathological biomarkers in estuarine fish species for the assessment of biological effects of contaminants. - Marine Environmental Research 55(2): 137-159.

[156] Strüssmann, C.A., Takashima, F. (1990): Hepatocyte nuclear size and nutritional condition of larval pejerrey, Odontesthes bonariensis (Cuvier et Valenciennes). - Jornal of Fish Biology 36: 59-65.

[157] Teien, H.-Ch., Kroglund, F. Salbu, B., Rosseland, B.O. (2006a): Gill reactivity of aluminium-species following liming. - Science of The Total Environment 358(1-3): 206220.

[158] Teien, H.-Ch., Standring, W.J.F., Salbu, B. (2006b): Mobilization of river transported colloidal aluminium upon mixing with seawater and subsequent deposition in fish gills. Science of the Total Environment 364(1-3): 149-164. 
[159] Terra, B.F., Araújo, F.G., Calza, C.F., Lopes, R.T., Teixeira, T.. (2008): Heavy metal in tissues of three fish species from different trophic levels in a tropical Brazilian river. Water, Air, and Soil Pollution 187(1-4): 275-284.

[160] The, S., Hung, S., The, F., Deng, D., Werner, I. (2005): Sublethal toxicity of orchard stormwater runoff in Sacramento splittail (Pogonichthys macrolepidotus) larvae. - Marine Environmental Research 59(3): 203-216.

[161] Thophon, S.K., Kruatrachue, M., Upathan, E.S., Pokthitiyook, P., Sahaphong, S., Jaritkhuan, S. (2003): Histopathological alterations of white sea bass, Lates calcarifer, in acute and subchronic cadmium exposure. - Environmental Pollution 121: 307-320.

[162] Tilak, K., Rao, K., Veeraiah, K. (2005): Effects of chlorpyrifos on histopathology of the fish Catla catla. - Journal of Ecotoxicology and Environmental Monitoring 15(2): 127 140.

[163] Tkacheva, V., Hyvärinen, H., Kukkonen, J., Ryzhkov, L.P., Holopainen, I.J. (2004): Toxic effects of mining effluents on fish gills in a subarctic lake system in NW Russia. Ecotoxicology and Environmental Safety 57: 278-289.

[164] Triebskorn, R., Köhler, H.-R., Honnen, W., Schramm, M., Adams, S.M., Müller, E.F. (1997): Induction of heat shock proteins, changes in liver ultrastructure, and alterations of fish behavior: are these biomarkers related and are they useful to reflect the state of pollution in the field? - Journal of Aquatic Ecosystem Stress and Recovery 6(1): 57-73.

[165] Triebskorn, R., Adam, S., Casper, H., Honnen, W., Pawert, M., Schramm, M., Schwaiger, J., Köhler H.-R. (2002): Biomarkers as diagnostic tools for evaluating effects of unknown past water quality conditions on stream organisms. - Ecotoxicology 11(6): 451-465.

[166] Triebskorn, R., Telcean, I., Casper, H., Farkas, A., Sandu, C., Stan, G., Colărescu, O., Dori, T., Köhler, H.-R. (2008): Monitoring pollution in River Mureş, Romania, part II: Metal accumulation and histopathology in fish. - Environmental Monitoring and Assessment 141(1-3): 177-188.

[167] van den Heuvel, M.R., Power, M., Richards, J., MacKinnon, M., Dixon, D.G. (2000): Disease and gill lesions in yellow perch (Perca flavescens) exposed to oil sands miningassociated waters. - Ecotoxicology and Environmental Safety 46: 334-341.

[168] van der Oost, R., Beyer, J., Vermeulen, N.P.E. (2003): Fish bioaccumulation and biomarkers in environmental risk assessment: A review. - Environmental Toxicology and Pharmacology 13:57-149.

[169] van Dyk, J.C., Pieterse, G.M., van Vuren, J.H.J. (2007): Histological changes in the liver of Oreochromis mossambicus (Cichlidae) after exposure to cadmium and zinc. Ecotoxicology and Environmental Safety 66(3): 432-440.

[170] van Dyk, J.C., Marchand, M.J., Smit, N.J., Pieterse, G.M. (2009): A histology-based fish health assessment of four commercially and ecologically important species from the Okavango Delta panhandle, Botswana. - African Journal of Aquatic Sciences 34: 273282.

[171] van Heerden, D., Vosloo, A., Nikinmaa, M. (2004): Effects of short-term copper exposure on gill structure, metallothionein and hypoxia-inducible factor-1á (HIF-1á) levels in rainbow trout (Oncorhynchus mykiss). - Aquatic Toxicology 69: 271-280.

[172] Varanka, Z., Rojik, I., Varanka, I., Nemcsók, J., Ábrahám, M. (2001): Biochemical and morphological changes in carp (Cyprinus carpio L.) liver following exposure to copper sulfate and tannic acid. - Comparative Biochemistry and Physiology 128(3): 467-477.

[173] Velcheva, I., Arnaudov, A., Georgieva, E. (2010a): Influence of zinc on gill morphology of Gibelio carp (Carassius gibelio). - Ecologia Balkanica 2: 19-23.

[174] Velcheva, I., Tomova, E., Arnaudova, D., Arnaudov, A. (2010b): Morphological investigation on gills and liver of freshwater fish from dam lake "Studen kladenets". Bulgarian Journal of Agricultural Science 16: 364-368

[175] Velmurugan, B., Selvanayagam, M., Cengiz, E. I., Unlu, E. (2007): Histopathology of lambda-cyhalothrin on tissues (gill, kidney, liver and intestine) of Cirrhinus mrigala. Environmental Toxicology and Pharmacology 24(3): 286-291. 
[176] Velmurugan, B., Selvanayagam, M., Cengiz, Elif I., Unlu, E. (2009): Histopathological changes in the gill and liver tissues of freshwater fish, Cirrhinus mrigala exposed to dichlorvos. - Brazilian Archives of Biology and Technology 52(5): 1291-1296.

[177] Vethaak, A.D., Bucke, D., Lang, T., Wester, P.W., Jol, J., Carr, M. (1992): Fish disease monitoring along a pollution transect: a case study using dab Limanda limanda in the German Bight. - Marine Ecology Progress Sereries 91: 173-192.

[178] Vethaak, A.D., Wester, P.W. (1996): Diseases of flounder Platichthys flesus in Dutch coastal and estuarine waters, with particular reference to environmental stress factors. II. Liver histopathology. - Diseases of Aquatic Organisms 26: 99-116.

[179] Viana, A. P., Frédou, F. L., da Silva Montes, C., Rocha, R.M. (2013): Fish histopathology and catalase activity as biomarkers of the environmental quality of the industrial district on the Amazon estuary, Brazil. - Acta Scientiarum 35(3): 395-401.

[180] Vicentini, C.A., Franceschini-Vicentini, I.B., Bombonato, M.T.S., Bertolucci, B., Lima, S.G., Santos, A.S. (2005): Morphological study of the liver in the teleost Oreochromis niloticus. - International Journal of Morphology 23(3): 211-216.

[181] Vigário, A.F., Sabóia-Morais, S.M.T. (2014): Effects of the 2,4-D herbicide on gills epithelia and liver of the fish Poecilia vivipara. - Pesqisa Veterinária Brasiliera 34(6): 523-528.

[182] Vigliano, F.A, Aleman, N., Quiroga, M.I., Nieto, J.M. (2006): Ultrastructural characterization of gills in juveniles of the Argentinian silverside, Odontesthes bonariensis (Valenciennes, 1835) (Teleostei: Atheriniformes). - Anatomia, Histologia, Embryologia 35: 76-83.

[183] Vinodhini, R., Narayanan, M. (2008): Heavy metal induced histopathological alterations in selected organs of the Cyprinus carpio L. (Common Carp). - International Journal of Environmental Research 3(1): 95-100.

[184] Walter, G.L., Jones, P.D., Giesy, J.P. (2000): Pathologic alterations in adult rainbow trout, Oncorhynchus mykiss, exposed to dietary 2,3,7,8-tetrachlorodibenzo-p-dioxin. Aquatic Toxicology 50: 287-299.

[185] Webb, D., Gagnon, M.M. (2009): The value of stress protein 70 as an environmental biomarker of fish health under field conditions. - Environmental Toxicology 24(3): 287295.

[186] Wester, P.W., Canton, J.H. (1994): The usefulness of histopathology in aquatic toxicity studies. - Comparative Biochemistry and Physiology 100: 115-117.

[187] Wester, P.W., Vethaak, A.D., van Muiswinkel, W.B. (1994): Fish as biomarkers in immunotoxicology. - Toxicology 86(3): 213-232.

[188] WHO International Programme on Chemical Safety (IPCS). 1993: Biomarkers and risk assessment: concepts and principles. Environmental Health Criteria 155, World Health Organization, Geneva.

[189] Wilson, J.M., Pierre, L. (2002): Fish gill morphology: inside out. - Journal of Experimental Zoology 293: 192-213.

[190] Wiseman, S., Vijayan, M.M. (2011): Aroclor 1254 disrupts liver glycogen metabolism and enhances acute stressor-mediated glycogenolysis in rainbow trout. - Comparative Biochemistry and Physiology 154: 254-260.

[191] Yancheva, V.S., Georgieva, E.S., Velcheva, I.G., Iliev, I.N., Vasileva, T.A., Petrova, S. T., Stoyanova, S.G. (2014): Biomarkers in european perch (Perca fluviatilis) liver from a metal-contaminated dam lake. - Biologia 69(11): 1615-1624.

[192] Yildirim, M.Z., Beni, A.C., Selvi, M., Ozkul, A., Erkoc, F., Kocak, O. (2006): Acute toxicity, behavioral changes, and histopathological effects of deltamethrin on tissues (gill, liver, brain, spleen, kidney, muscle, skin) of nile tilapia Oreochromis niloticus L. fingerlings. - Environmental Toxicology 21(6): 614-620.

[193] Yildirim, M.Z., Benli, K.C., Selvi, M., Ozkul, A., Erko, F., Kocak, O. (2006): Acute toxicity behavioural changes and histopathological effects of deltamethrin on tissues 
(gills, liver, brain, spleen, kidney, muscle, skin) of Nile Tilapia (Oreochromis niloticus) fingerlings. - Environmental Toxicology 21: 614-620.

[194] Yılmaz, F., Özdemir, N., Demirak, A., Tuna, L. (2007): Heavy metal levels in two fish species Leuciscus cephalus and Lepomis gibbosus. - Food Chemistry 100(2): 830-835.

[195] Youson, H. P., Butler, D. G., Trisorus, K. (1989): The kidney, adrenocortical homolog, and corpuscles of stannius in the Cockscomb prickleback Anoplarchus purpurescens. Japanese Journal of Ichtyology 36(1): 91-103.

[196] Zimmerli, S., Bernet, D., Burkhardt-Holm, P., Schmidt-Posthaus, H., Vonlanthen, P., Wahli, T., Segner, H. (2007): Assessment of fish health status in four Swiss rivers showing a decline of brown trout catches. - Aquatic Sciences 69:11-25. 